\title{
Biomarker distributions in surface sediments from the Kara and Laptev seas (Arctic Ocean): indicators for organic-carbon sources and sea-ice coverage
}

\author{
Xiaotong Xiao*, Kirsten Fahl, Ruediger Stein \\ Alfred Wegener Institute for Polar and Marine Research, Am Alten Hafen 26, Bremerhaven 27568, Germany
}

\section{A R T I C L E I N F O}

\section{Article history:}

Received 29 June 2012

Received in revised form

13 November 2012

Accepted 28 November 2012

Available online 22 February 2013

\section{Keywords:}

Arctic Ocean

Kara and Laptev seas

Sea ice

Biomarkers

$\mathrm{IP}_{25}$

$\mathrm{PIP}_{25}$

$\mathrm{C}_{25}$ HBI diene

\begin{abstract}
A B S T R A C T
Studies of spatial and temporal changes in modern and past sea-ice occurrence may help to understand the processes controlling the recent decrease in Arctic sea-ice cover. Here, we determined concentrations of $\mathrm{IP}_{25}$, a novel biomarker proxy for sea ice developed in recent years, phytoplankton-derived biomarkers (brassicasterol and dinosterol) and terrigenous biomarkers (campesterol and $\beta$-sitosterol) in the surface sediments from the Kara and Laptev seas to estimate modern spatial (seasonal) sea-ice variability and organic-matter sources. $\mathrm{C}_{25}$-HBI dienes and trienes were determined as additional palaeoenvironmental proxies in the study area. Furthermore, a combined phytoplankton- $\mathrm{IP}_{25}$ biomarker approach (PIP $_{25}$ index) is used to reconstruct the modern sea-ice distribution more quantitatively. The terrigenous biomarkers reach maximum concentrations in the coastal zones and estuaries, reflecting the huge discharge by the major rivers Ob, Yenisei and Lena. Maxima in phytoplankton biomarkers indicating increased primary productivity were found in the seasonally ice-free central part of the Kara and Laptev seas. Neither $\mathrm{IP}_{25}$ nor $\mathrm{PIP}_{25}$, however, shows a clear and simple correlation with satellite sea-ice distribution in our study area due to the complex environmental conditions in our study area and the transportation process of sea-ice diatom in the water column. Differences in the diene/ $/ \mathrm{P}_{25}$ and triene/ $/ \mathrm{P}_{25}$ ratios point to different sources of these HBIs and different environmental conditions. The diene $/ \mathrm{IP}_{25}$ ratio seems to correlate positively with sea-surface temperature, while negatively with salinity distributions.
\end{abstract}

(c) 2012 Elsevier Ltd. All rights reserved.

\section{Introduction}

The polar sea ice is a fundamental component of Earth's climate system, contributing to heat reduction (albedo), deep-water formation and gas exchange between the ocean and the atmosphere. The annual cycle of sea-ice formation and melting processes plays an important role in determining the global climate, furthermore it influences the primary productivity of surface water masses, the benthos in the abyss and the habitat for polar marine mammals and birds (Siegel et al., 1997; Stein, 2008; Dieckmann and Hellmer, 2010). In this context the rapid shrinking sea ice, especially in the Arctic Ocean, is of major interest for the entire community (Johannessen et al., 1995; Francis et al., 2005; Stroeve et al., 2005, 2007, 2008; Thomas and Dieckmann, 2010). In order to understand processes controlling the recent dramatic reduction in Arctic sea-ice cover, it is essential to determine spatial and temporal

\footnotetext{
* Corresponding author. Tel.: +49 (0) 47148312206.

E-mail address: Xiaotong.Xiao@awi.de (X. Xiao).
}

changes in sea-ice occurrence and its natural variability in the present and past.

The recent Arctic sea-ice conditions have been determined by microwave satellite remote sensing observation (Johannessen et al., 1995, 1999; Comiso and Parkinson, 2004; Stroeve et al., 2005, 2007, 2008) as well as from the data set based on cruise reports, aerial observation and digitization of the sea-ice charts for the early 20th century (Rothrock et al., 1999; Walsh and Chapman, 2001; Rayner et al., 2003), while the reconstruction of the palaeo-latitudinal extent of sea ice is mainly derived from geological data, including sedimentological, geochemical and micropalaeotological parameters of surface sediments and sediment cores (Cremer, 1999; Fahl and Stein, 1999, 2007; Knies et al., 2001; Polyakova and Stein, 2004; Armand and Leventer, 2010). However, the use of some of these parameters, e.g. siliceous frustules and calcareous microfossils as indicators of sea ice, has been limited due to the restricted preservation of diatoms and foraminifera in Arctic Ocean sediments (Wollenburg et al., 2001, 2004; Armand and Leventer, 2010). Therefore, stable and well-preserved biomarker proxies derived from sea ice, have been developed recently. The novel sea-ice 
biomarker $\mathrm{IP}_{25}$, a mono-unsaturated highly branched isoprenoid (HBI) alkene with 25 carbon atoms biosynthesized specifically by sea-ice algae, has been used to reconstruct the sea-ice distribution (Belt et al., 2007). These authors also showed that this biomarker is stable in marine sediments due to its resistance to degradation in the water column and to other diagenetic processes in the sediment. $\mathrm{IP}_{25}$ data were compared with historical sea-ice records and other proxy data (e.g. isotopic composition, foraminifera and particle size) in further studies (Massé et al., 2008; Vare et al., 2009), which provided evidence for the stable preservation of this new proxy in marine sediments. The occurrence of this monoene in sediment cores from the North Icelandic Shelf, the central Canadian Arctic Archipelago, the central Arctic Ocean and the northern Fram Strait, consistent with other palaeoclimatic parameters, has demonstrated that $\mathrm{IP}_{25}$ is a reliable proxy to reconstruct past sea-ice distribution (Massé et al., 2008; Müller et al., 2009; Vare et al., 2009; Belt et al., 2010; Fahl and Stein, 2012; Stein et al., 2012). Stein and Fahl (2013) could show that $\mathrm{IP}_{25}$ is even preserved in sediments as old as $2.2 \mathrm{Ma}$. The absence of $\mathrm{IP}_{25}$ illustrates ice-free or permanent ice conditions, whereas the presence of $\mathrm{IP}_{25}$ indicating spring sea-ice occurrence (Belt et al., 2007; Müller et al., 2009). Recently, the combination of brassicasterol derived from openwater phytoplankton with $\mathrm{IP}_{25}$ enables the reconstruction of various sea-ice conditions (Müller et al., 2009, 2011). The absence of both biomarkers demonstrates a permanent ice cover, whereas the absence of $\mathrm{IP}_{25}$ with elevated brassicasterol suggests ice-free conditions. On the other hand, the occurrence of both biomarkers reflects the seasonal ice margin. Müller et al. (2011) have reconstructed modern sea-ice distribution using a combined phytoplankton marker - $\mathrm{IP}_{25}$ approach ("PIP 25 index"), which may provide a more quantitative evaluation of paleo sea-ice conditions to be incorporated into models for forecasting further climate change.

\section{Study area}

In this study, we analysed surface sediments from the Kara and Laptev seas, fringing the northeastern rim of the Eurasian continent and covering large part of the Siberian shelf area. Both seas are of essential importance for water-mass and sea-ice transport into the Arctic Ocean (Lisitsyn and Vinogradov, 1995). The hydrography of this area is influenced by the inflow of warm Atlantic water and supply of freshwater from major rivers (Jones, 2001; Peterson et al., 2002) (Fig. 1).

Relatively warm, dense water from the Atlantic Ocean enters the Arctic Ocean through Fram Strait between Greenland and Svalbard and through the Barents Sea. This water transport occurs through two branches, the Fram Strait Branch and the Barents Sea Branch (Fig. 1). The Barents Sea Branch crosses the Barents Sea and enters the Kara Sea via the St. Anna Trough. The Fram Strait Branch flows eastward along the continental slope north of the Barents Sea after entering the Eurasian Basin. Here, north of the Kara Sea, part of the Fram Strait Branch returns in the vicinity of the Nansen-Gakkel Ridge, and part joins the Barents Sea Branch to continue to cross the boundary of the Kara and Laptev seas (Schauer et al., 1997; Jones, 2001). The cold, freshwater from the Kara and Laptev seas joins the Transpolar Drift, flowing from the Siberian Coast towards the Fram Strait.

River inflow into the Kara and Laptev seas is dominantly contributed by three of the largest rivers on Earth: Yenisei, Ob and Lena, which drain about $60 \%$ of Eurasian Arctic landmass and transport myriads of organic matter into the Kara and Laptev seas (Peterson et al., 2002; Fahl et al., 2003; Stein et al., 2004; Stein and Fahl, 2004a,b). This supply of freshwater substantially affects the process of freezing, transport, and melting of sea ice (Aagaard and Carmack, 1989), and is particularly important for coastal fast ice processes (Divine et al., 2004; Bareiss and Görgen, 2005).

The ice realm of the Kara and Laptev seas is characterized by strong seasonal and interannual variability, comprising a variety of sea-ice conditions such as drift ice, fast ice, ice massifs and coastal polynyas (Parkinson et al., 1999; Bareiss and Görgen, 2005, Fig. $2 \mathrm{~A}-\mathrm{C}$ ). Corresponding to the sea-ice conditions, the seasurface temperature (SST) also shows a distinct seasonal variability in this area and increases gradually from north to south in summer (Fig. 2D). The sea-ice cover reaches its maximum in March and then starts to retreat northward (Fig. 2A). The sea-ice extent reaches its minimum in September with major parts becoming ice-free (Fig. 2B). With respect to sea-ice conditions, the Kara and Laptev seas present a complex system. First, the sea-ice cover of these areas is characterized by large zones of fast ice (motionless ice along the shore line) during winter (Pfirman et al., 1995; Polyakov et al., 2003; Divine et al., 2004; Bareiss and Görgen,

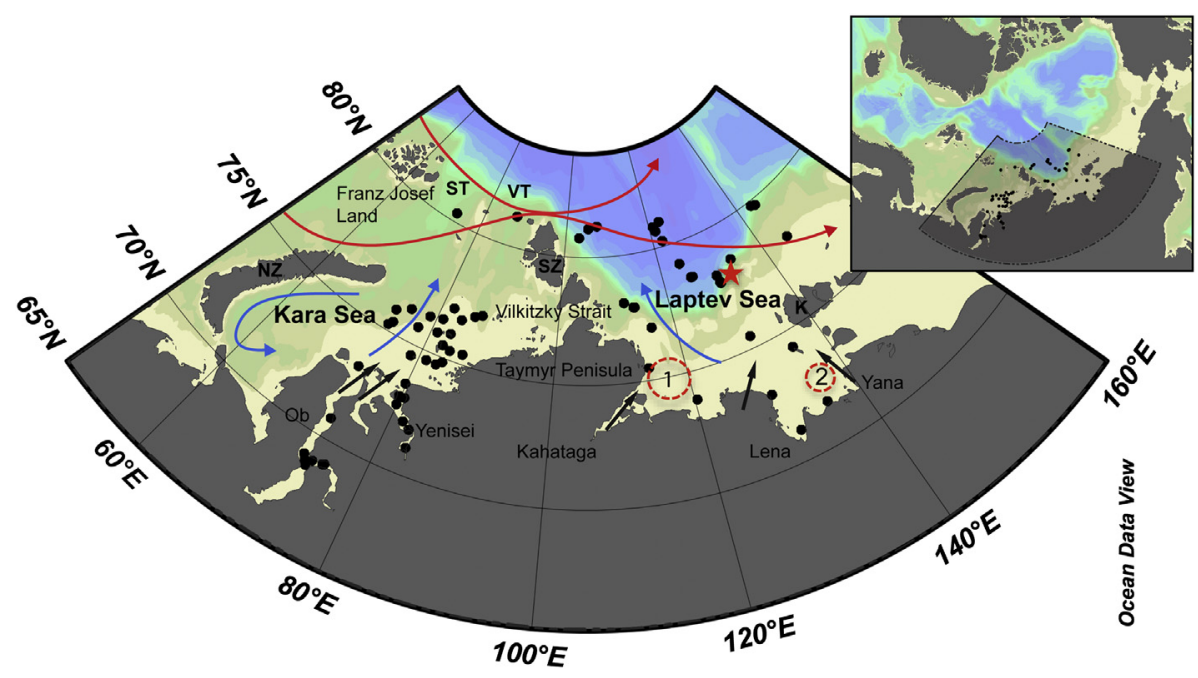

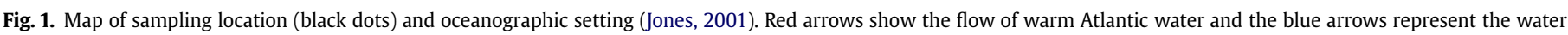

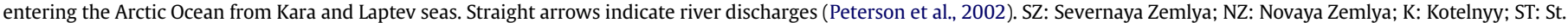

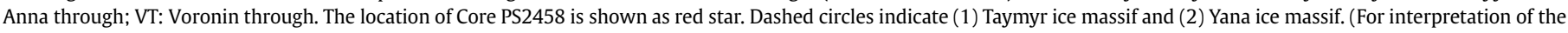
references to colour in this figure legend, the reader is referred to the web version of this article.) 
A

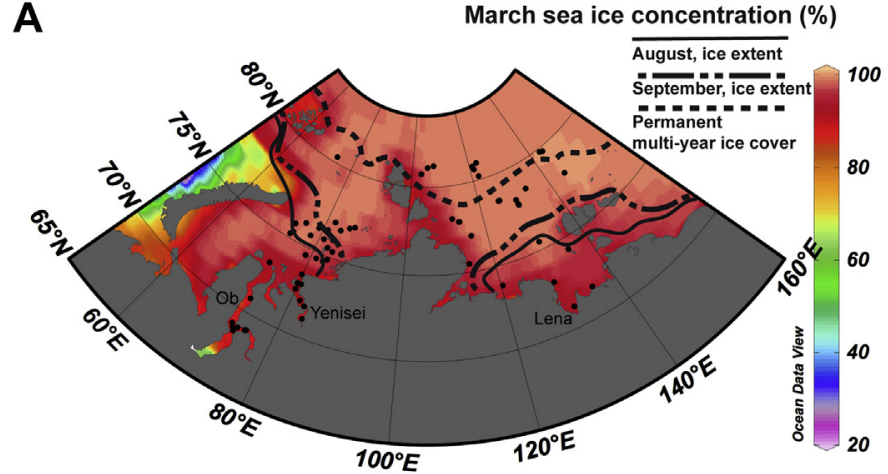

C

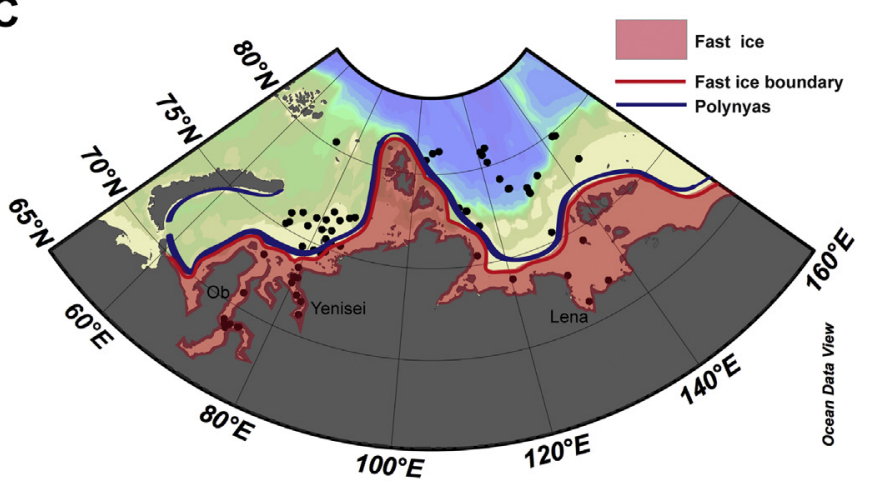

B

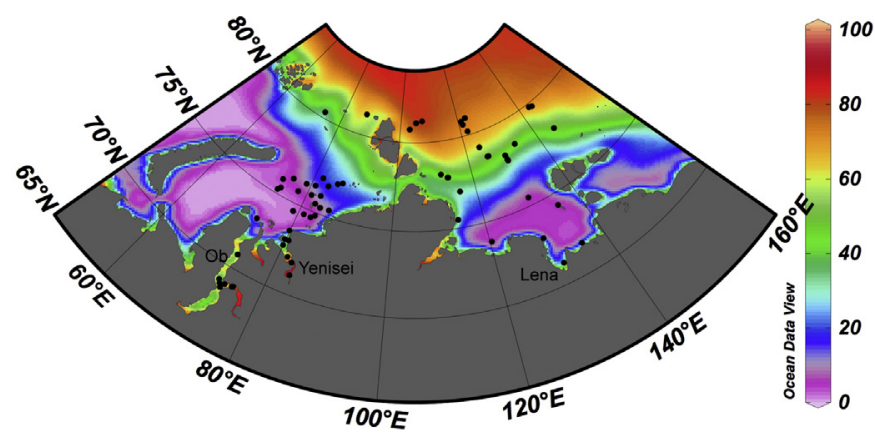

D

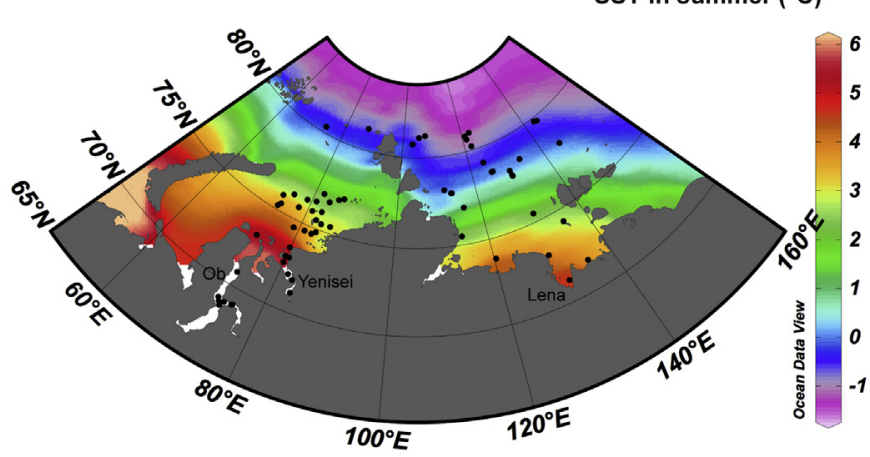

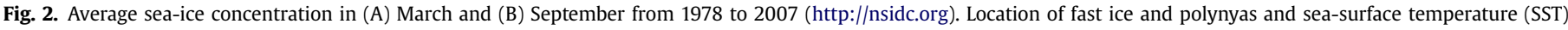

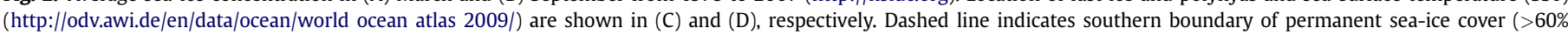
throughout the year). August and September boundaries of sea-ice cover represent the $30 \%$ isoline for the specific months.

2005; Fig. 2C) and the winter polynyas (long and narrow zones of open water) occur along the boundary of the fast ice on the continental shelf (Martin and Cavalieri, 1989; Dethleff et al., 1998; Bareiss and Görgen, 2005; Kern, 2008; Fig. 2C). Second, during summer sea ice is transported into the Kara and Laptev seas from the Arctic Basin, whereas during winter sea ice is exported towards the Arctic Basin (Mironov et al., 2007a). Furthermore, sea ice from the Kara and Laptev seas is exported by the Transpolar Drift throughout the Arctic Ocean to the Greenland Sea and North Atlantic (Meese et al., 1997; Mironov et al., 2007b). Third, the strong fluvial input influences the formation and melting of sea ice (Fahl et al., 2003; Stein et al., 2004; Rivera et al., 2006), especially the fast-ice processes. This region also includes several archipelagos on the shelf, which are glaciated at present: Novaya Zemlya, Severnaya Zemlya, and Kotelnyy.

\section{Materials and methods}

\subsection{Sediment sampling}

The surface sediment samples from the Laptev Sea shelf and slope were taken in 1993 during the RV Polarstern expedition ARK IX/4 (Fütterer, 1994) and the Transdrift I expedition with RV Ivan Kireyev (Kassens and Karpiy, 1994), and during RV Polarstern expedition ARK XXVI/3 in 2011 (TransArc, Schauer, 2012). The surface sediment samples from the $\mathrm{Ob}$ and Yenisei transects and the inner and central Kara Sea shelf were taken during the Akademik Boris Petrov expeditions in 2000, 2001and 2002 (Stein and Stepanets, 2001, 2002; Schoster and Levitan, 2003). The sampling was carried out with a giant boxcorer and a multicorer. Whereas total organic carbon was measured in all samples (cf., Stein and
Fahl, 2004a,b), the biomarker parameters were determined on selected samples (see Table 1).

\subsection{Biomarker analyses}

For biomarker analyses, the freeze-dried surface sediments were extracted by an Accelerated Solvent Extractor (DIONEX, ASE $\left.200 ; 100{ }^{\circ} \mathrm{C}, 5 \mathrm{~min}, 1000 \mathrm{psi}\right)$ using dichloromethane:methanol (2:1 $\mathrm{v} / \mathrm{v})$. For quantification the internal standards 7-hexylnonadecane, squalane and cholesterol- $\mathrm{d}_{6}$ (cholest-5-en-3 $\beta-$ ol- $\mathrm{D}_{6}$ ) were added before any analytical treatment. Further separation of hydrocarbons and sterols was carried out via open-column chromatography using $\mathrm{SiO}_{2}$ as stationary phase. Hydrocarbons were eluted with $n$ hexane $(5 \mathrm{ml})$ and sterols with ethylacetate: $n$-hexane $(20: 80 \mathrm{v} / \mathrm{v}$; $6 \mathrm{ml})$. The latter were silylated with $500 \mu \mathrm{lBSTFA}\left(60{ }^{\circ} \mathrm{C}, 2 \mathrm{~h}\right)$. Compound analyses of both fractions were carried out on an Agilent $6850 \mathrm{GC}$ (30 m HP-5MS column, $0.25 \mathrm{~mm}$ i.d., $0.25 \mu \mathrm{m}$ film thickness) coupled to an Agilent $5975 \mathrm{C}$ VL mass selective detector. The GC oven was heated from $60{ }^{\circ} \mathrm{C}$ to $150{ }^{\circ} \mathrm{C}$ at $15^{\circ} \mathrm{C} \mathrm{min}-1$, and then at $10{ }^{\circ} \mathrm{C} \mathrm{min}^{-1}$ to $320^{\circ} \mathrm{C}$ (held $15 \mathrm{~min}$ ) for the analysis of hydrocarbons and at $3{ }^{\circ} \mathrm{C} \mathrm{min}^{-1}$ to $320^{\circ} \mathrm{C}$ (held $20 \mathrm{~min}$ ) for sterols, respectively. Mass spectrometer conditions were $70 \mathrm{eV}$ and $230{ }^{\circ} \mathrm{C}$ (ion source). Helium was used as carrier gas. Individual compound identification was based on comparisons of their retention times with that of reference compounds and on comparisons of their mass spectra with published data (Boon et al., 1979; Volkman, 1986; Johns et al., 1999; Belt et al., 2007). Biomarker concentrations were calculated on the basis of their individual GC-MS ion responses compared with those of respective internal standards. For further details concerning the $\mathrm{C}_{25}$ - HBI alkenes $\left(\mathrm{IP}_{25}, \mathrm{C}_{25}\right.$ - $\mathrm{HBI}$ diene, and $\mathrm{C}_{25}$-HBI triene) quantification see Müller et al. (2011) and Fahl and Stein (2012). Brassicasterol (24-methylcholesta-5,22E-dien-3 $\beta$ - 
Table 1

Sample coordinates and biomarker data. TOC data from Stein and Fahl (2004a,b).

\begin{tabular}{|c|c|c|c|c|c|c|c|c|c|c|}
\hline Station Nr. & Longitude & Latitude & $\begin{array}{l}\text { TOC } \\
\text { (wt.\%) }\end{array}$ & $\begin{array}{l}\mathrm{IP}_{25} \\
(\mu \mathrm{g} / \mathrm{g} \mathrm{OC})\end{array}$ & $\begin{array}{l}\text { HBI diene } \\
(\mu \mathrm{g} / \mathrm{g} O C)\end{array}$ & $\begin{array}{l}\text { HBI triene } \\
(\mu \mathrm{g} / \mathrm{g} O C)\end{array}$ & $\begin{array}{l}\text { Brassicasterol } \\
(\mu \mathrm{g} / \mathrm{g} \text { OC })\end{array}$ & $\begin{array}{l}\text { Dinosterol } \\
(\mu \mathrm{g} / \mathrm{g} \mathrm{OC})\end{array}$ & $\begin{array}{l}\text { Campesterol } \\
(\mu \mathrm{g} / \mathrm{g} \mathrm{OC})\end{array}$ & $\begin{array}{l}\beta \text {-Sitosterol } \\
(\mu \mathrm{g} / \mathrm{g} \mathrm{OC})\end{array}$ \\
\hline BP00-02 & 74.20 & 75.40 & 0.54 & 8.35 & 9.94 & 0.08 & 88.73 & 23.35 & 122.62 & 152.19 \\
\hline ВР00-04 & 81.01 & 76.42 & 0.44 & 10.65 & 10.21 & 0.11 & 120.54 & 30.27 & 111.41 & 168.95 \\
\hline ВР00-05 & 81.01 & 75.84 & 0.59 & 8.53 & 7.13 & 0.08 & 116.77 & 23.72 & 80.49 & 133.71 \\
\hline ВР00-07 & 81.14 & 74.66 & 1.49 & 8.02 & 9.86 & 0.35 & 120.14 & 16.70 & 108.57 & 242.68 \\
\hline ВР00-08 & 82.64 & 74.66 & 1.31 & 7.52 & 8.05 & 0.18 & 120.49 & 36.23 & 90.65 & 158.03 \\
\hline ВР00-09 & 83.43 & 74.83 & 1.00 & 4.98 & 8.72 & 0.35 & 88.72 & 30.89 & 104.11 & 137.33 \\
\hline ВР00-13 & 80.55 & 72.93 & 1.75 & 0.55 & 3.13 & 0.05 & 116.63 & 28.26 & 206.25 & 465.84 \\
\hline ВР00-14 & 79.79 & 72.93 & 1.78 & 1.59 & 4.13 & 0.10 & 95.74 & 20.63 & 136.30 & 247.44 \\
\hline ВР00-15 & 81.60 & 72.05 & 0.71 & 0.00 & 1.47 & 0.00 & 62.67 & 25.24 & 125.34 & 399.57 \\
\hline ВР00-16 & 82.62 & 71.83 & 2.16 & 0.00 & 4.96 & 0.00 & 87.76 & 20.38 & 235.90 & 447.51 \\
\hline ВР00-17 & 83.09 & 71.11 & 0.43 & 0.00 & 1.51 & 0.00 & 88.22 & 9.63 & 129.67 & 228.06 \\
\hline ВР00-22 & 79.92 & 72.57 & 1.44 & 0.19 & 1.22 & 0.04 & 68.40 & 19.52 & 138.39 & 286.32 \\
\hline ВР00-23 & 79.86 & 73.48 & 1.06 & 1.91 & 4.38 & 0.08 & 122.79 & 28.31 & 154.08 & 254.20 \\
\hline ВР00-26 & 77.96 & 75.71 & 1.02 & 10.40 & 14.79 & 0.61 & 101.10 & 37.16 & 157.93 & 163.15 \\
\hline ВР00-27 & 78.93 & 76.30 & 0.97 & 8.46 & 8.35 & 0.19 & 139.19 & 44.07 & 138.95 & 192.29 \\
\hline ВР00-28 & 83.88 & 76.66 & 0.49 & 6.99 & 9.45 & 0.17 & 106.30 & 48.47 & 105.04 & 161.05 \\
\hline ВР00-29 & 85.76 & 76.94 & 0.68 & 4.89 & 6.56 & 0.09 & 66.81 & 35.04 & 88.48 & 156.24 \\
\hline ВР00-30 & 83.04 & 75.99 & 0.82 & 8.72 & 12.72 & 0.73 & 61.80 & 43.95 & 103.91 & 112.42 \\
\hline ВР00-31 & 82.55 & 75.46 & 1.01 & 7.44 & 13.34 & 0.45 & 61.46 & 21.34 & 111.08 & 85.66 \\
\hline ВР00-35 & 83.80 & 75.35 & 1.31 & 4.61 & 4.59 & 0.29 & 133.36 & 30.27 & 113.20 & 439.44 \\
\hline ВР00-36 & 81.96 & 76.96 & 0.83 & 3.85 & 2.48 & 0.09 & 139.16 & 52.34 & 114.90 & 227.34 \\
\hline ВР00-38 & 73.24 & 73.20 & 1.15 & 0.68 & 2.03 & 0.00 & 24.19 & 17.92 & 101.27 & 112.63 \\
\hline ВР01-38 & 86.92 & 77.09 & 1.02 & 7.33 & 9.25 & 0.37 & 93.31 & 28.92 & 127.69 & 142.58 \\
\hline ВР01-43 & 85.83 & 75.38 & 1.26 & 3.85 & 2.88 & 0.22 & 65.37 & 18.80 & 158.02 & 236.51 \\
\hline ВР01-64 & 73.65 & 75.89 & 1.03 & 3.57 & 3.64 & 0.18 & 103.51 & 26.69 & 160.20 & 281.39 \\
\hline ВР01-67 & 73.76 & 75.24 & 1.00 & 4.53 & 4.74 & 0.17 & 81.35 & 27.75 & 153.53 & 146.66 \\
\hline ВР01-73a & 73.63 & 68.87 & 1.16 & 0.00 & 2.65 & 0.00 & 30.71 & 29.27 & 307.65 & 327.46 \\
\hline ВР01-74 & 74.37 & 68.97 & 0.90 & 0.00 & 3.98 & 0.00 & 17.30 & 31.46 & 357.30 & 339.21 \\
\hline ВР01-75 & 75.70 & 69.08 & 1.64 & 0.00 & 1.19 & 0.00 & 51.14 & 37.90 & 666.89 & 525.19 \\
\hline ВР01-76 & 75.50 & 69.03 & 1.59 & 0.00 & 1.97 & 0.00 & 30.79 & 25.46 & 360.75 & 306.79 \\
\hline ВР01-78 & 74.00 & 68.67 & 0.93 & 0.00 & 5.77 & 0.00 & 25.28 & 24.50 & 127.94 & 236.81 \\
\hline ВР01-79 & 73.23 & 69.05 & 1.06 & 0.00 & 3.09 & 0.00 & 75.44 & 27.02 & 406.33 & 418.50 \\
\hline ВР02-01 & 75.73 & 76.22 & 0.63 & 4.20 & 6.40 & 0.00 & 50.47 & 22.18 & 44.62 & 80.54 \\
\hline ВP02-02 & 73.99 & 80.33 & 1.12 & 3.38 & 5.76 & 0.08 & 91.68 & 25.72 & 123.91 & 121.41 \\
\hline ВP02-03 & 78.88 & 74.58 & 1.66 & 4.31 & 8.34 & 0.42 & 160.78 & 41.90 & 129.85 & 135.05 \\
\hline BP02-05 & 73.73 & 70.83 & 0.49 & 0.00 & 0.00 & 0.00 & 31.33 & 21.11 & 184.55 & 233.14 \\
\hline KD9523-8 & 135.46 & 74.31 & 0.92 & 8.08 & 8.17 & 0.14 & 38.22 & 22.98 & 138.49 & 143.17 \\
\hline KD9529-12 & 135.74 & 71.75 & 0.90 & 1.19 & 4.87 & 0.04 & 44.09 & 29.72 & 358.28 & 417.90 \\
\hline KD9533-11 & 131.35 & 71.23 & 0.51 & 1.31 & 1.72 & 0.00 & 97.61 & 31.98 & 172.91 & 196.64 \\
\hline KD9541 & 129.94 & 73.00 & 0.79 & 3.65 & 6.41 & 0.00 & 74.99 & 24.80 & 141.18 & 278.37 \\
\hline KD9548-13 & 130.69 & 75.47 & 0.90 & 4.53 & 7.79 & 0.11 & 67.33 & 21.73 & 137.37 & 142.66 \\
\hline KD9565-12 & 120.35 & 73.85 & 0.41 & 8.92 & 23.98 & 0.49 & 64.65 & 26.58 & 98.51 & 148.67 \\
\hline KD9568-8 & 114.50 & 75.48 & 0.44 & 7.54 & 17.69 & 0.60 & 68.35 & 29.90 & 106.15 & 134.39 \\
\hline KD9572-1 & 116.04 & 77.02 & 0.41 & 4.45 & 7.66 & 0.31 & 85.54 & 36.36 & 145.91 & 137.01 \\
\hline PS2721-1 & 144.89 & 78.01 & 0.70 & 6.10 & 5.13 & 0.23 & 180.37 & 94.02 & 116.39 & 254.92 \\
\hline PS2734-3 & 130.05 & 77.85 & 0.67 & 5.38 & 5.35 & 0.10 & 81.55 & 60.66 & 46.24 & 232.03 \\
\hline PS2735-5 & 130.04 & 77.93 & 0.83 & 3.94 & 3.54 & 0.14 & 78.11 & 67.85 & 44.23 & 192.21 \\
\hline PS2736-3 & 129.99 & 78.18 & 0.90 & 4.66 & 4.17 & 0.07 & 99.24 & 93.92 & 59.05 & 201.01 \\
\hline PS2741-1 & 105.39 & 81.10 & 1.18 & 2.30 & 2.24 & 0.09 & 59.44 & 39.33 & 26.84 & 104.35 \\
\hline PS2740-8 & 107.41 & 81.20 & 0.93 & 1.49 & 0.91 & 0.00 & 23.79 & 29.31 & 11.66 & 61.72 \\
\hline PS2743-7 & 103.20 & 80.74 & 0.46 & 1.83 & 0.97 & 0.00 & 25.83 & 25.07 & 17.41 & 52.90 \\
\hline PS2747-8 & 133.72 & 78.51 & 0.33 & 11.43 & 6.67 & 0.08 & 55.85 & 51.80 & 37.07 & 135.13 \\
\hline PS2767-6 & 143.99 & 79.74 & 0.83 & 2.90 & 1.51 & 0.00 & 37.73 & 32.24 & 20.92 & 81.81 \\
\hline PS2768-3 & 143.09 & 79.82 & 0.76 & 7.22 & 6.15 & 0.19 & 39.37 & 31.86 & 19.36 & 76.93 \\
\hline PS2774-2 & 122.71 & 80.96 & 0.66 & 2.58 & 1.49 & 0.00 & 14.39 & 20.06 & 12.50 & 52.94 \\
\hline PS2778-1 & 113.51 & 77.93 & 0.93 & 5.58 & 7.29 & 0.45 & 118.72 & 75.79 & 107.91 & 187.42 \\
\hline PS2780-5 & 113.73 & 77.91 & 0.45 & 7.94 & 11.35 & 0.67 & 112.97 & 74.55 & 83.49 & 166.14 \\
\hline PS2781-52 & 111.91 & 78.13 & 1.02 & 6.67 & 13.01 & 0.60 & 79.94 & 55.04 & 43.52 & 121.52 \\
\hline PS2791-5 & 87.50 & 81.17 & 0.53 & 4.93 & 7.79 & 0.24 & 87.32 & 28.92 & 28.56 & 92.55 \\
\hline PS78/275-1 & 120.97 & 80.82 & 0.76 & 2.28 & 1.50 & 0.00 & 30.63 & 7.87 & 19.07 & 91.12 \\
\hline PS78/276-6 & 121.27 & 80.63 & 0.73 & 3.32 & 2.65 & 0.00 & 37.42 & 6.67 & 18.06 & 104.38 \\
\hline PS78/277-2 & 122.20 & 80.21 & 0.85 & 2.96 & 2.80 & 0.00 & 41.78 & 9.14 & 17.18 & 95.38 \\
\hline PS78/280-6 & 124.04 & 79.15 & 0.66 & 3.24 & 2.86 & 0.00 & 40.48 & 9.52 & 15.82 & 81.70 \\
\hline PS78/283-3 & 125.35 & 78.52 & 0.81 & 6.59 & 7.23 & 0.17 & 63.92 & 19.29 & 20.59 & 103.49 \\
\hline PS78/285-6 & 125.72 & 78.50 & 1.02 & 3.96 & 3.80 & 0.10 & 43.09 & 9.59 & 15.94 & 77.63 \\
\hline
\end{tabular}

ol), dinosterol $(4 \alpha, 23,24 \mathrm{R}$-trimethyl-5 $\alpha$-cholest-22E-en-3 $\beta$-ol $)$, campesterol (24-methylcholest-5-en-3b-ol) and $\beta$-sitosterol (24ethylcholest-5-en-3b-ol) were quantified as trimethylsilyl ethers using gas chromatography (for details see Fahl and Stein, 1999). The biomarker concentrations were corrected to the amount of extracted sediment.

\subsection{Calculation of "PIP 25 index"}

In order to assess more quantitative reconstructions of sea-ice distributions, Müller et al. (2011) have calculated a phytoplankton-IP 25 index ( $\mathrm{PIP}_{25}$ ), which provided new insights into the evaluation of the sea-ice distribution in the northern North Atlantic 
(Fram Strait). In our study, we calculated $\mathrm{P}_{\mathrm{B}} \mathrm{IP}_{25}$ (using brassicasterol) and $\mathrm{P}_{\mathrm{D}} \mathrm{IP} 25$ (using dinosterol), using the following formulae (for details see Müller et al., 2011):

$\mathrm{P}_{\mathrm{B}} \mathrm{IP}_{25}=\mathrm{IP}_{25} /\left(\mathrm{IP}_{25}+\right.$ brassicasterol $\left.* c\right)$

$\mathrm{P}_{\mathrm{D}} \mathrm{IP}_{25}=\mathrm{IP}_{25} /\left(\mathrm{IP}_{25}+\right.$ dinosterol $\left.^{*} c\right)$

With $c=$ mean $\mathrm{IP}_{25}$ concentration/mean (1) brassicasterol or (2) dinosterol concentrations of all surface sediments.

\subsection{Data presentation and storage}

Maps of sea-ice distribution, sea-surface temperature, total organic carbon, and biomarker distributions were generated using the Ocean Data View program (Schlitzer, 2012).

All data are available in the data bank PANGAEA (http://dx.doi. org/10.1594/PANGAEA.803232).

\section{Results}

\subsection{Total organic carbon (TOC)}

The TOC values are about $0.2-3 \%$ and $0.5-2.5 \%$ in Kara Sea and Laptev Sea, respectively (Fig. 3; Fernandes and Sicre, 2000; Fahl et al., 2001; Stein et al., 2003; Stein and Fahl, 2004a,b). In the Kara Sea, maximum TOC values of $1.5-2.5 \%$ occur in the estuaries and the St. Anna Through, separated by relatively low TOC values $(<1 \%)$ in the central Kara Sea. The TOC distribution pattern of the Laptev Sea is similar to that of Kara Sea. Maximum values of up to $2 \%$ occur in the vicinity of Lena Delta.

\subsection{Sterols}

The concentrations of phytoplankton biomarkers (brassicasterol and dinosterol) and terrigenous biomarkers (campesterol and $\beta$ sitosterol) in surface sediments are shown in distribution maps (Fig. 4). The distribution patterns of both brassicasterol and dinosterol are very similar. The highest brassicasterol $(62-180 \mu \mathrm{g} / \mathrm{g}$ TOC) and dinosterol (48-94 $\mu \mathrm{g} / \mathrm{g}$ TOC) contents occur in the Central Kara Sea and along the continental slope of Laptev Sea, and they decrease towards the deep sea and river mouths, respectively. Low concentrations were detected for brassicasterol (17-88 $\mu \mathrm{g} / \mathrm{g}$ TOC) and dinosterol (10-38 $\mu \mathrm{g} / \mathrm{g}$ TOC) in the Ob and Yenisei rivers. In contrast, the maximum values of the terrigenous biomarkers (campesterol, 141-667 $\mu \mathrm{g} / \mathrm{g}$ TOC; $\beta$-sitosterol, $233-525 \mu \mathrm{g} / \mathrm{g}$ TOC) are localized in the rivers and estuaries and correlate with elevated

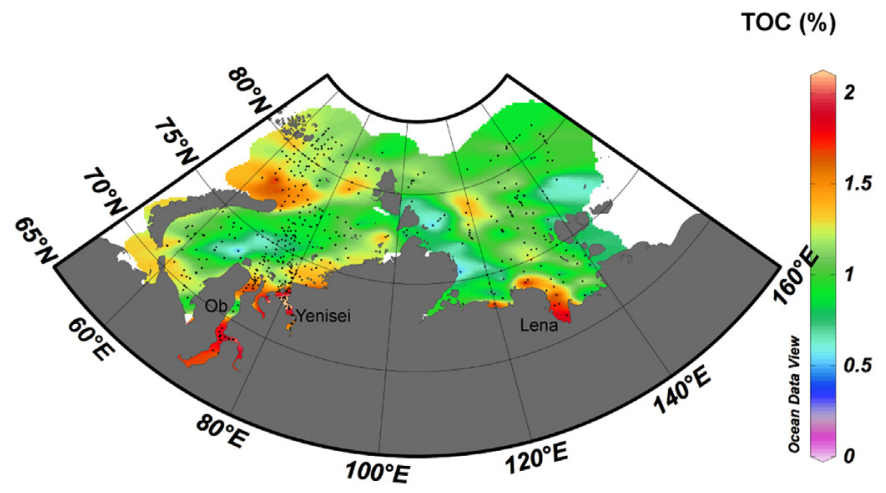

Fig. 3. Distribution map of TOC (Total Organic Carbon) in surface sediments from the Kara and Laptev seas (Stein and Fahl, 2004a,b).
TOC contents (Fig. 3). The campesterol and $\beta$-sitosterol concentrations decrease gradually northward and reach the minimum values (12-21 $\mu \mathrm{g} / \mathrm{g}$ TOC and 53-104 $\mu \mathrm{g} / \mathrm{g}$ TOC, respectively) along the continental slope to the north of Kara and Laptev seas.

\section{3. $C_{25}$ highly branched isoprenoid (HBI) alkenes and Phytoplankton- $I P_{25}$ index}

The mono-unsaturated $\mathrm{C}_{25}$-HBIs $\left(\mathrm{IP}_{25}\right.$, Fig. 5A) show highest contents (3-11 $\mu \mathrm{g} / \mathrm{g}$ TOC) in the Central Kara Sea and then decrease gradually from the central area to the rivers, reaching low concentrations $(0.2-0.7 \mu \mathrm{g} / \mathrm{g}$ TOC) in the vicinity of estuaries. Directly in the $\mathrm{Ob}$ and Yenisei rivers $\mathrm{IP}_{25}$ is completely absent. In the Laptev Sea, minimum concentrations of $\mathrm{IP}_{25}(1.5-2.3 \mu \mathrm{g} / \mathrm{g}$ TOC) are found in sediments from the continental margin. In contrast, maximum $\mathrm{IP}_{25}$ values (4-11 $\mu \mathrm{g} / \mathrm{g}$ TOC) occur along the outer shelf and continental slope. From here, $\mathrm{IP}_{25}$ values slightly decrease southward but obviously increase in the east of Taymyr Peninsula $(8-9 \mu \mathrm{g} / \mathrm{g} \mathrm{TOC})$ and southwest of Kotelnyy (5-8 $\mu \mathrm{g} / \mathrm{g}$ TOC). Low $\mathrm{IP}_{25}$ values were detected near the Lena River mouth.

In general, the $\mathrm{P}_{\mathrm{B}} \mathrm{IP} 25$ index (Fig. 5B) and the $\mathrm{P}_{\mathrm{D}} \mathrm{IP}_{25}$ index (supplementary material, Fig. S1A) display a distribution quite similar to the $\mathrm{IP}_{25}$ data. Maxima occur in the central Kara Sea as well as east of Taymyr Peninsula and around Kotelnyy Island.

High $\mathrm{C}_{25}$-HBI diene values (Fig. 6A) occur in the central Kara Sea (6-14 $\mu \mathrm{g} / \mathrm{g}$ TOC), east of Taymyr Peninsula $(8-20 \mu \mathrm{g} / \mathrm{g}$ TOC) and southwest of Kotelnyy (5-8 $\mu \mathrm{g} / \mathrm{g}$ TOC), while decreasing values were determined in the rivers and adjacent continental margin. $\mathrm{C}_{25}$-HBI trienes (Fig. 6B) occur in relatively high concentrations $(0.31-0.67 \mu \mathrm{g} / \mathrm{g}$ TOC) in the western Laptev Sea, along the east coast of Taymyr Peninsula; they are completely absent in the rivers and deep-sea environment. The diene/ $/ \mathrm{IP}_{25}$ ratio (Fig. 6C; Table 2) as well as the triene $/ \mathrm{IP}_{25}$ ratio (Fig. S1B, supplementary material; Table 2) generally increase from the deep sea towards the river. Their correlations are shown in Fig. 7.

\section{Discussion}

Strong seasonal and regional variability in the Kara and Laptev sea-ice extent are reflected in changes in organic-carbon sources, i.e. phytoplankton and sea-ice algae production as well as terrigenous input. Thus, we determined concentrations of $\mathrm{C}_{25}$ - $\mathrm{HBI}$ alkenes $\left(\mathrm{IP}_{25}\right.$ diene and triene), open-water phytoplankton-derived biomarkers (brassicasterol and dinosterol) and terrigenous biomarkers (campesterol and $\beta$-sitosterol) to reconstruct recent surface-water characteristics with special emphasis on sea-ice conditions in these areas. The interpretation of our biomarker data is illustrated in a schematic diagram (Fig. 9), showing the general sea-ice formation and melting processes in the Siberian marginal seas. Additionally, it reveals the variable terrigenous input and productivity of ice algae and phytoplankton during different seasons.

\subsection{Organic carbon source and terrigenous biomarker distributions}

The TOC preserved in surface sediments is predominantly originated either from primary production or terrigenous input. In the rivers and estuaries of the Kara and Laptev seas, the organic matter is almost entirely of terrigenous origin (Stein and Fahl, 2004a,b), which is well reflected by the organic geochemical bulk parameters. High $\mathrm{C} / \mathrm{N}$ ratios $>10$, low $\mathrm{HI}$ (hydrogen index) $<100 \mathrm{mgHC} /$ gOC and light $\delta^{13} \mathrm{C}_{\text {org }}$ values of about $-28.7 \%$ o (Ob), $-27 \%$ (Yenisei) and $-27.1 \%$ (Lena) reflect the predominantly terrigenous origin of TOC (Fahl and Stein, 1997; Rachold and Hubberten, 1999; Fernandes and Sicre, 2000; Krishnamurthy et al., 2001; Fahl et al., 2003). North of the $\mathrm{Ob}$ and Yenisei estuaries, for example, the proportion of 
A

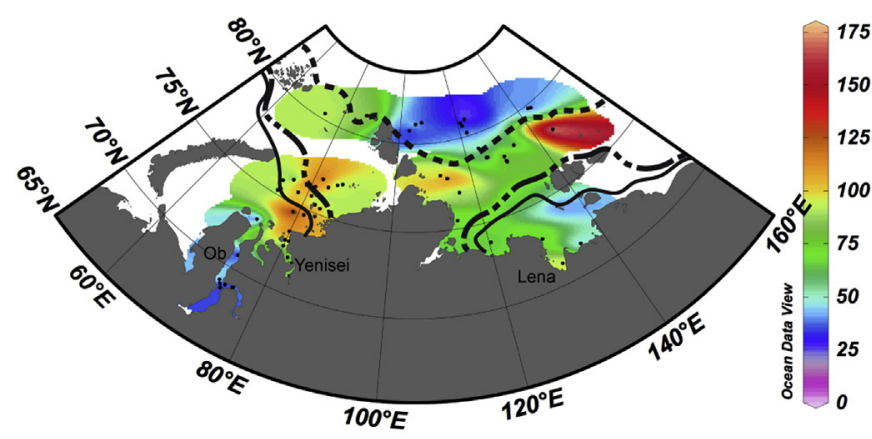

C

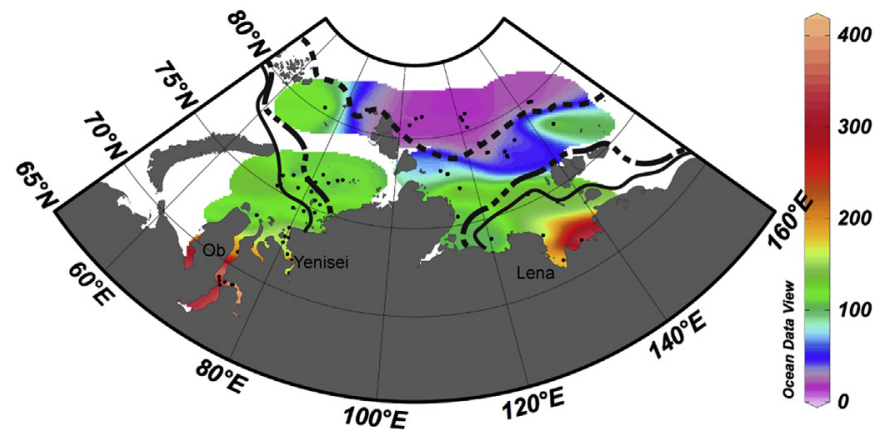

B

Dinosterol $(\mu \mathrm{g} / \mathrm{g}$ TOC)

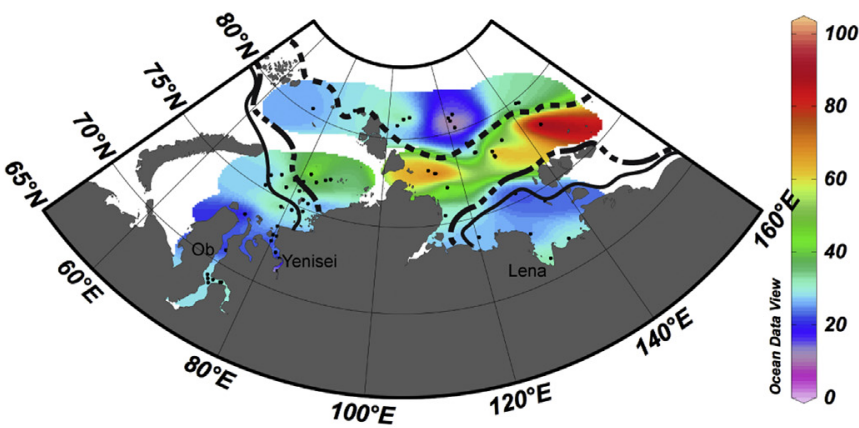

D

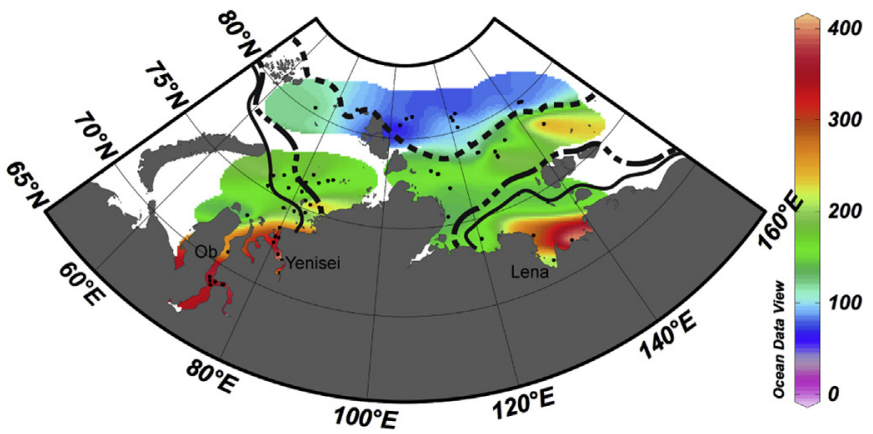

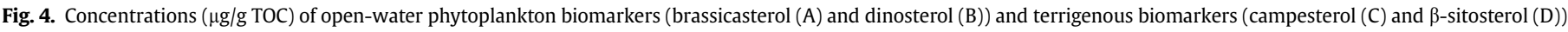
in surface sediments from the Kara and Laptev seas. For explanation of dashed and solid lines, see Fig. 2.

terrigenous organic carbon ranges between 66 and 89\% of the TOC (Fernandes and Sicre, 2000). Nearly the same conditions were recorded in the Laptev Sea off the Lena River (Stein and Fahl, 2004b). Furthermore, TOC values are influenced by freshwater diatom productivities to some degree (Cremer, 1999; Polyakova, 2003). In contrast, the relatively low TOC values in the central part of Kara and Laptev seas are attributed to the decreasing terrigenous organic-carbon input towards the north. This northward decrease in terrigenous input is also reflected in a characteristic decrease of the biomarkers campesterol and $\beta$-sitosterol (Fig. 4C, D), synthesized by higher plants (Huang and Meinschein, 1976; Volkman, 1986).

Highest concentrations of campesterol and $\beta$-sitosterol in the rivers and estuaries agree with observations of Fahl and Stein (1997), Fernandes and Sicre (2000) and Gaye et al. (2007), who detected light $\delta^{13} \mathrm{C}$ and $\delta^{15} \mathrm{~N}$ values, and high concentrations of long-chain $n$-alkanes $\left(C_{27}+C_{29}+C_{31}\right)$ of about $350-410 \mu \mathrm{g} / \mathrm{g}$ TOC in the estuaries of the Kara Sea rivers and about 600 to $>1000 \mu \mathrm{g} / \mathrm{g}$
TOC off the Laptev Sea rivers, especially off the Lena Delta. This can be interpreted as a result of strong riverine input and the "marginal filter" effect near the river mouths, where most of the organic matter accumulates in the surface sediments (Lisitzin, 1995). Furthermore, high concentrations of campesterol and $\beta$-sitosterol (Fig. 4C, D), TOC (Fig. 3), and long-chain $n$-alkanes (Fahl et al., 2001) were determined north of the estuaries $\left(>72^{\circ} \mathrm{N}\right)$, following the submarine channels. Moreover, sediment organic matter can be incorporated into the sea ice during ice formation on the shallow shelf and then transported to the open ocean via sea-ice export to the Arctic Basin, reflecting seasonal ice variability, inducing the seaice exchange between marginal seas and the Arctic Ocean (Nürnberg et al., 1994; Eicken et al., 1997; Pfirman et al., 1997).

\subsection{Marine biomarker distributions and sea-ice conditions}

Minimum concentrations of $\mathrm{IP}_{25}$ (Fig. 5A) and phytoplankton biomarkers (Fig. 4A,B) occur in surface sediments from the adjacent
A

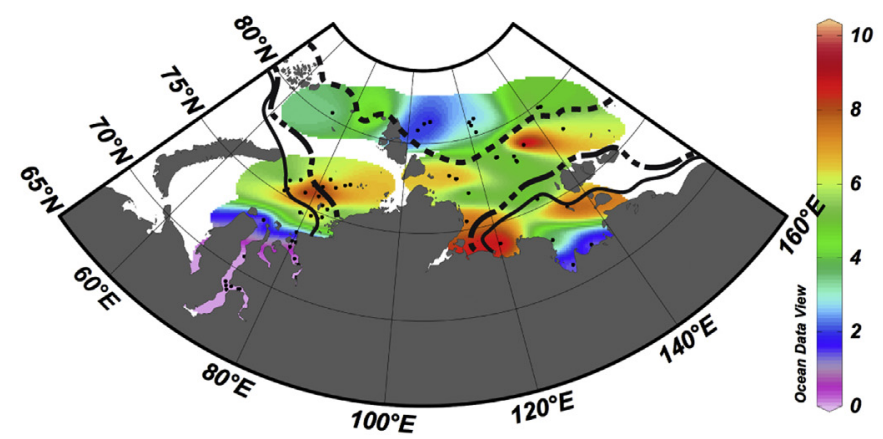

B

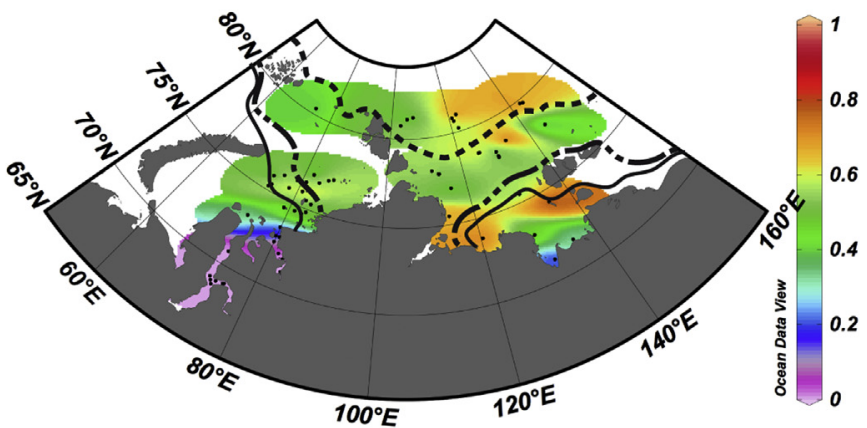

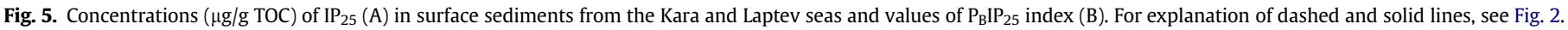


A

Diene $(\mu \mathrm{g} / \mathrm{g}$ TOC)

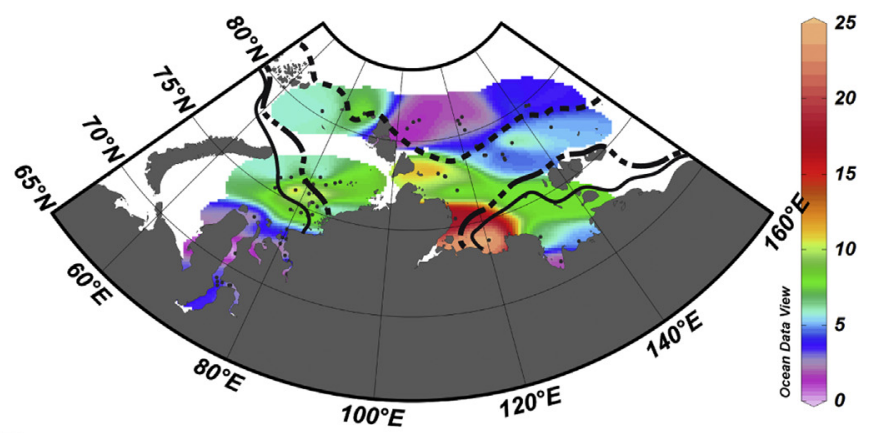

B

Triene ( $\mu \mathrm{g} / \mathrm{g}$ TOC)

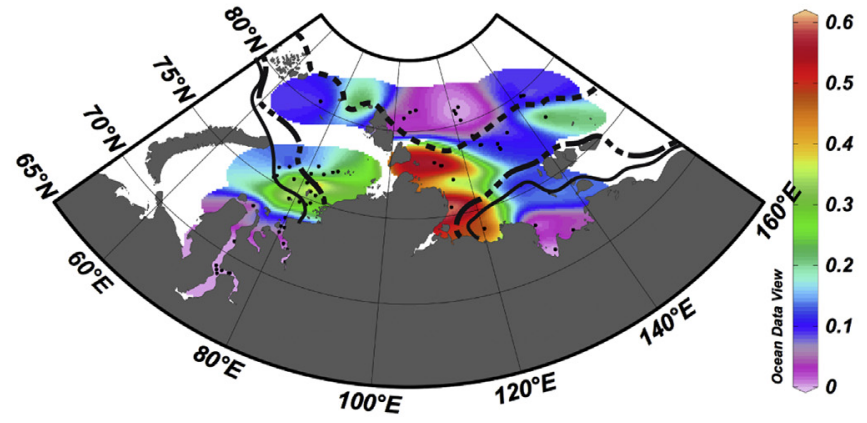

C

Diene//P25

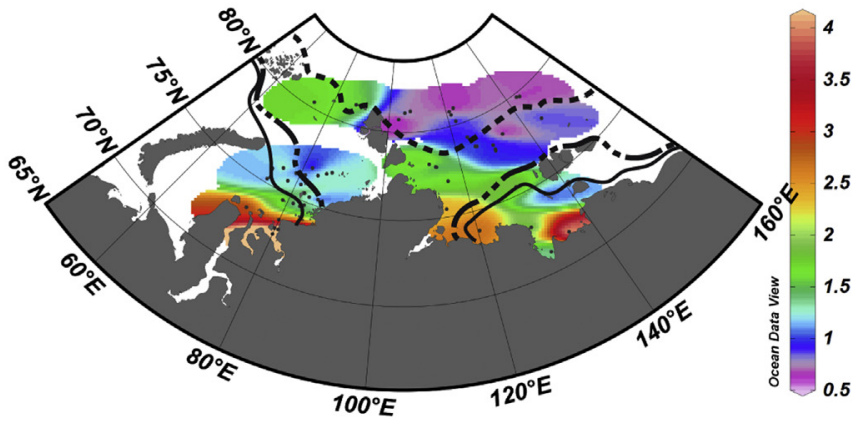

Fig. 6. Concentrations ( $\mu \mathrm{g} / \mathrm{g}$ TOC) of $\mathrm{C}_{25}$ HBIs diene $(\mathrm{A})$ and $\mathrm{C}_{25}$ HBIs triene (B) in surface sediments from the Kara and Laptev seas and values of $\mathrm{IP}_{25} /$ diene ratios $(C)$. For explanation of dashed and solid lines, see Fig. 2.

continental margin $\left(>80^{\circ} \mathrm{N}\right.$, northeast of Severnaya Zemlya), interpreted as all-season permanent sea-ice cover in this area. This is also supported by the combined phytoplankton- $\mathrm{IP}_{25}$ biomarker approach. High $\mathrm{P}_{\mathrm{B}} \mathrm{IP}_{25}$ values $(0.65-0.79$, Fig. 5B), based on both low contents of $\mathrm{IP}_{25}$ and brassicasterol, point to permanent sea-ice conditions north of the Laptev Sea continental margin. The sea ice along the northern continental slope survives the spring and summer melting and remains at the end of melting period in September. Thus, this sea-ice cover causes a restricted marine primary productivity due to the extremely limited light penetration (Cremer, 1999; Belchansky and Douglas, 2002).

In contrast, the co-occurrence of increased $\mathrm{IP}_{25}$ values and openwater phytoplankton biomarkers from Franz Josef Land to southwest of Severnaya Zemlya $\left(>75^{\circ} \mathrm{N}\right.$; including the central part of Kara Sea) and from Vilkitzky Strait to the north of Kotelnyy, along the southern continental slope, lead to the assumption of an existing sea-ice edge during summer (Figs. 2B and 8) resulting in favourable living conditions for both ice algae and open-water phytoplankton (cf., Müller et al., 2011). At these sites, the sea-ice cover along the outer shelf becomes thinner in the summer and
Table 2

$\mathrm{PIP}_{25}$ index, and diene/ $/ \mathrm{IP}_{25}$ and triene $/ \mathrm{IP}_{25}$ ratios. $\mathrm{PIP}_{25}$ index has been calculated using a formula (for details see Müller et al., 2011). n.d.: no data available.

\begin{tabular}{|c|c|c|c|c|c|c|}
\hline Station Nr. & Longitude & Latitude & $\begin{array}{l}\mathrm{P}_{\mathrm{B}} \mathrm{IP}_{25} \\
(c=0.056)\end{array}$ & $\begin{array}{l}\mathrm{P}_{\mathrm{D}} \mathrm{IP} \\
(c=0.132)\end{array}$ & $\begin{array}{l}\text { Diene/ } \\
\mathrm{IP}_{25}\end{array}$ & $\begin{array}{l}\text { Triene/ } \\
\mathrm{IP}_{25}\end{array}$ \\
\hline BP00-02 & 74.20 & 75.40 & 0.64 & 0.74 & 1.19 & 0.010 \\
\hline ВР00-04 & 81.01 & 76.42 & 0.62 & 0.74 & 0.96 & 0.010 \\
\hline ВР00-05 & 81.01 & 75.84 & 0.58 & 0.74 & 0.84 & 0.009 \\
\hline ВР00-07 & 81.14 & 74.66 & 0.55 & 0.80 & 1.23 & 0.043 \\
\hline ВР00-08 & 82.64 & 74.66 & 0.54 & 0.63 & 1.07 & 0.024 \\
\hline ВР00-09 & 83.43 & 74.83 & 0.51 & 0.57 & 1.75 & 0.070 \\
\hline ВР00-13 & 80.55 & 72.93 & 0.08 & 0.14 & 5.71 & 0.090 \\
\hline ВР00-14 & 79.79 & 72.93 & 0.24 & 0.38 & 2.59 & 0.061 \\
\hline ВР00-15 & 81.60 & 72.05 & 0.00 & 0.00 & n.d. & n.d. \\
\hline ВР00-16 & 82.62 & 71.83 & 0.00 & 0.00 & n.d. & n.d. \\
\hline ВР00-17 & 83.09 & 71.11 & 0.00 & 0.00 & n.d. & n.d. \\
\hline ВР00-22 & 79.92 & 72.57 & 0.05 & 0.07 & 6.31 & 0.212 \\
\hline ВР00-23 & 79.86 & 73.48 & 0.22 & 0.35 & 2.30 & 0.043 \\
\hline ВР00-26 & 77.96 & 75.71 & 0.66 & 0.69 & 1.42 & 0.059 \\
\hline ВР00-27 & 78.93 & 76.30 & 0.53 & 0.61 & 0.99 & 0.023 \\
\hline ВР00-28 & 83.88 & 76.66 & 0.55 & 0.54 & 1.35 & 0.024 \\
\hline ВР00-29 & 85.76 & 76.94 & 0.58 & 0.53 & 1.34 & 0.019 \\
\hline ВР00-30 & 83.04 & 75.99 & 0.72 & 0.62 & 1.46 & 0.084 \\
\hline ВР00-31 & 82.55 & 75.46 & 0.69 & 0.74 & 1.79 & 0.060 \\
\hline ВР00-35 & 83.80 & 75.35 & 0.39 & 0.55 & 0.99 & 0.062 \\
\hline ВР00-36 & 81.96 & 76.96 & 0.34 & 0.37 & 0.64 & 0.023 \\
\hline ВР00-38 & 73.24 & 73.20 & 0.34 & 0.24 & 2.97 & 0.000 \\
\hline ВР01-38 & 86.92 & 77.09 & 0.59 & 0.67 & 1.26 & 0.051 \\
\hline ВР01-43 & 85.83 & 75.38 & 0.52 & 0.62 & 0.75 & 0.058 \\
\hline ВР01-64 & 73.65 & 75.89 & 0.39 & 0.52 & 1.02 & 0.049 \\
\hline ВР01-67 & 73.76 & 75.24 & 0.51 & 0.57 & 1.05 & 0.038 \\
\hline ВР01-73a & 73.63 & 68.87 & 0.00 & 0.00 & n.d. & n.d. \\
\hline ВР01-74 & 74.37 & 68.97 & 0.00 & 0.00 & n.d. & n.d. \\
\hline ВР01-75 & 75.70 & 69.08 & 0.00 & 0.00 & n.d. & n.d. \\
\hline ВР01-76 & 75.50 & 69.03 & 0.00 & 0.00 & n.d. & n.d. \\
\hline ВР01-78 & 74.00 & 68.67 & 0.00 & 0.00 & n.d. & n.d. \\
\hline ВР01-79 & 73.23 & 69.05 & 0.00 & 0.00 & n.d. & n.d. \\
\hline ВР02-01 & 75.73 & 76.22 & 0.61 & 0.60 & 1.53 & 0.000 \\
\hline ВP02-02 & 73.99 & 80.33 & 0.41 & 0.51 & 1.70 & 0.025 \\
\hline BP02-03 & 78.88 & 74.58 & 0.33 & 0.45 & 1.94 & 0.097 \\
\hline BP02-05 & 73.73 & 70.83 & 0.00 & 0.00 & n.d. & n.d. \\
\hline KD_9523-8 & 135.46 & 74.31 & 0.80 & 0.74 & 1.01 & 0.017 \\
\hline KD_9529-12 & 135.74 & 71.75 & 0.33 & 0.24 & 4.08 & 0.037 \\
\hline KD_9533-11 & 131.35 & 71.23 & 0.20 & 0.25 & 1.31 & 0.000 \\
\hline KD_9541 & 129.94 & 73.00 & 0.47 & 0.54 & 1.75 & 0.000 \\
\hline KD_9548-13 & 130.69 & 75.47 & 0.55 & 0.63 & 1.88 & 0.026 \\
\hline KD_9565-12 & 120.35 & 73.85 & 0.72 & 0.73 & 2.69 & 0.055 \\
\hline KD_9568-8 & 114.50 & 75.48 & 0.67 & 0.67 & 2.35 & 0.080 \\
\hline KD_9572-1 & 116.04 & 77.02 & 0.49 & 0.50 & 1.72 & 0.070 \\
\hline PS2721-1 & 144.89 & 78.01 & 0.39 & 0.34 & 0.84 & 0.038 \\
\hline PS2734-3 & 130.05 & 77.85 & 0.55 & 0.42 & 0.99 & 0.019 \\
\hline PS2735-5 & 130.04 & 77.93 & 0.48 & 0.32 & 0.90 & 0.035 \\
\hline PS2736-3 & 129.99 & 78.18 & 0.47 & 0.29 & 0.90 & 0.015 \\
\hline PS2738-5 & 105.36 & 81.10 & 0.42 & 0.32 & 0.97 & 0.041 \\
\hline PS2740-8 & 107.41 & 81.20 & 0.54 & 0.29 & 0.62 & 0.000 \\
\hline PS2743-7 & 103.20 & 80.74 & 0.57 & 0.37 & 0.53 & 0.000 \\
\hline PS2747-8 & 133.72 & 78.51 & 0.79 & 0.64 & 0.58 & 0.007 \\
\hline PS2767-6 & 143.99 & 79.74 & 0.59 & 0.42 & 0.52 & 0.000 \\
\hline PS2768-3 & 143.09 & 79.82 & 0.77 & 0.65 & 0.85 & 0.026 \\
\hline PS2774-2 & 122.71 & 80.96 & 0.77 & 0.51 & 0.58 & 0.000 \\
\hline PS2778-1 & 113.51 & 77.93 & 0.47 & 0.37 & 1.31 & 0.081 \\
\hline PS2780-5 & 113.73 & 77.91 & 0.57 & 0.46 & 1.43 & 0.085 \\
\hline PS2781-52 & 111.91 & 78.13 & 0.61 & 0.49 & 1.95 & 0.090 \\
\hline PS2791-5 & 87.50 & 81.17 & 0.51 & 0.58 & 1.58 & 0.049 \\
\hline PS78/275-1 & 120.97 & 80.82 & 0.57 & 0.69 & 0.66 & 0.000 \\
\hline PS78/276-6 & 121.27 & 80.63 & 0.61 & 0.79 & 0.80 & 0.000 \\
\hline PS78/277-2 & 122.20 & 80.21 & 0.56 & 0.71 & 0.95 & 0.000 \\
\hline PS78/280-6 & 124.04 & 79.15 & 0.59 & 0.72 & 0.88 & 0.000 \\
\hline PS78/283-3 & 125.35 & 78.52 & 0.65 & 0.72 & 1.10 & 0.026 \\
\hline PS78/285-6 & 125.72 & 78.50 & 0.62 & 0.76 & 0.96 & 0.026 \\
\hline
\end{tabular}

thus light penetration allows algae growth. This interpretation is in agreement with the enriched marine fatty acids observed near the sea-ice edge of the Laptev Sea, where the melting processes induce phytoplankton blooms (Fahl et al., 2001). Furthermore, winter polynyas occur where a summer sea-ice edge exists, resulting in an 

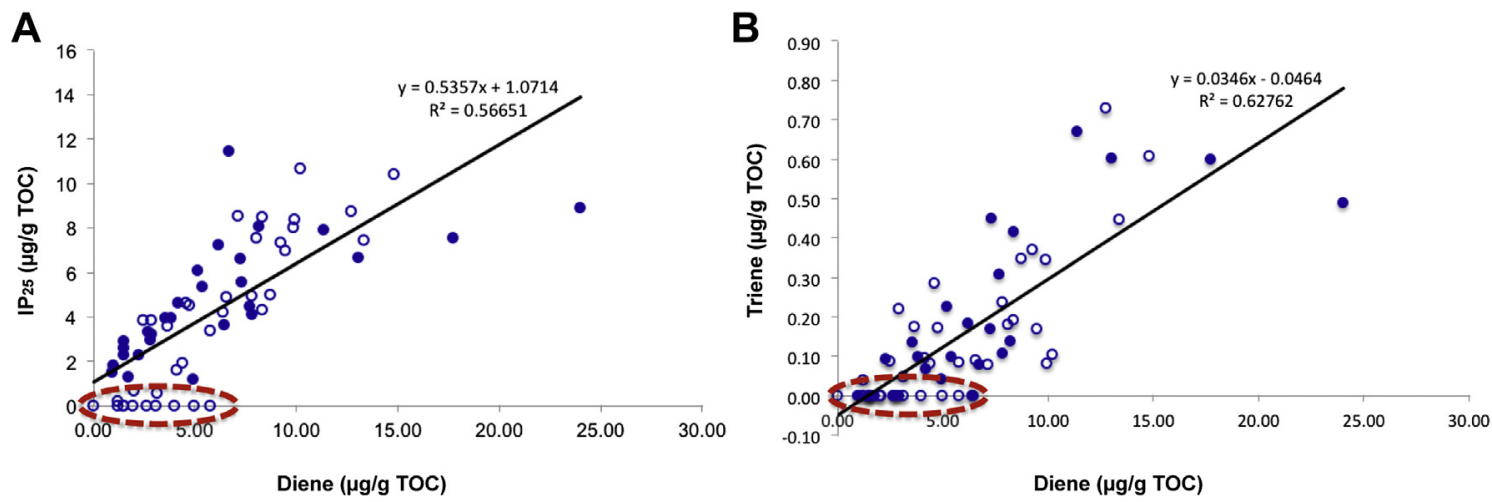

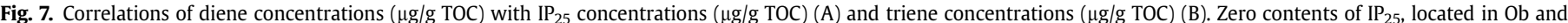

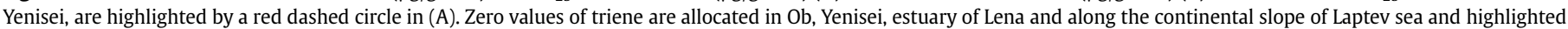

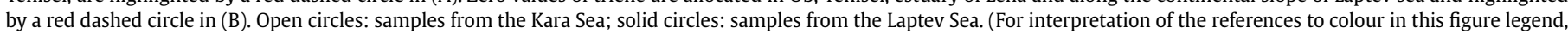
the reader is referred to the web version of this article.)

early bloom of primary productivity in April and May (for locations of polynyas see Mironov et al., 2007b; Fig. 2C). High concentrations of marine biomarkers in the central Kara Sea result from spring blooms of both sea-ice algae and phytoplankton in the Central Kara polynya (Gaye et al., 2007; Kern, 2008). These findings agree with the investigations of Polyakova (2003), who described the interrelation between the distribution of sea-ice diatoms and sea-ice cover during spring and summer and, in this context, extremely high abundance of these algae at the location of the winter polynya. Regarding the polynyas in the Laptev Sea, high $\mathrm{IP}_{25}$, brassicasterol and dinosterol values east of the Vilkitzky Strait and north of Kotelnyy (Figs. 4A, B and 5A) are probably caused by an enhanced primary productivity near the Northeastern Taymyrskaya and North Novosibirskaya polynyas during spring (Dethleff et al., 1998; Karklin et al., 2007). Similar results were published by Cremer (1999), reporting a dominance of a sea-ice diatom assemblage in sediments from the central and northwestern Laptev Sea shelf and low abundances of these diatoms in the deep sea. All samples with high abundance of sea-ice diatoms occur north of the polynyas (Cremer, 1999). In addition, elevated $\mathrm{P}_{\mathrm{B}} \mathrm{IP}_{25}$ values (0.64-0.72) occur in the areas along the northern shelf of the Kara and Laptev seas and the central part of both marginal seas (Fig. 5B), suggesting favourable living conditions for sea-ice algae and phytoplankton produced by a relatively stable sea-ice edge in summer.

$\mathrm{IP}_{25}$ values gradually decline southward from the central part of the Kara Sea, reflecting a reduced sea-ice cover from the north to the south. Different from the distribution trend of $\mathrm{IP}_{25}$ in Kara Sea,
$\mathrm{IP}_{25}$ values decrease less gradually towards south in Laptev Sea (Fig. 5A). Maximum $\mathrm{IP}_{25}$ values are found in the sediments east of Taymyr Peninsula and southwest of Kotelnyy in the southern Laptev Sea. In general, sea-ice conditions in these areas reflect a clear seasonal variability with sea ice melting during the summer. In accordance with these observations the $\delta^{18} \mathrm{O}$ and $\delta^{13} \mathrm{C}$ composition of benthic foraminiferal calcite in the Laptev Sea reflects ice-free conditions during summer and sea-ice cover during winter (Bauch et al., 2004). However, two stationary ice fields occasionally remain during summer: the Taymyr ice massif east of Taymyr Peninsula and Severnaya Zemlya and the Yana ice massif in the south-eastern Laptev Sea (Karklin et al., 2007; for locations see Fig. 1), which probably provide favourable conditions for sea icediatom growth during summer (Fig. 8C). Bareiss and Görgen (2005) noted these two ice massifs on the satellite-derived seaice concentration chart of Laptev Sea from August 1984. Maximum $\mathrm{P}_{\mathrm{B}} \mathrm{IP}_{25}(0.67-0.80)$ due to high $\mathrm{IP}_{25}$ concentrations, are probably related to the occurrence of these ice massifs surviving into the summer in areas characterized by seasonal sea-ice variability. Reduced concentrations of both brassicasterol and dinosterol near the Yana ice massif are probably caused by unsuitable environmental conditions, while the higher values of both sterols near the Taymyr ice massif east of Taymyr Peninsula can be related to the occurrence of the Eastern Taymyrskaya and Anabaro-Lenskaya polynyas (Martin and Cavalieri, 1989; Karklin et al., 2007).

Both $\mathrm{IP}_{25}$ and phytoplankton biomarker concentrations diminish towards the river mouths (Figs. 4A, B and 5A), indicating less
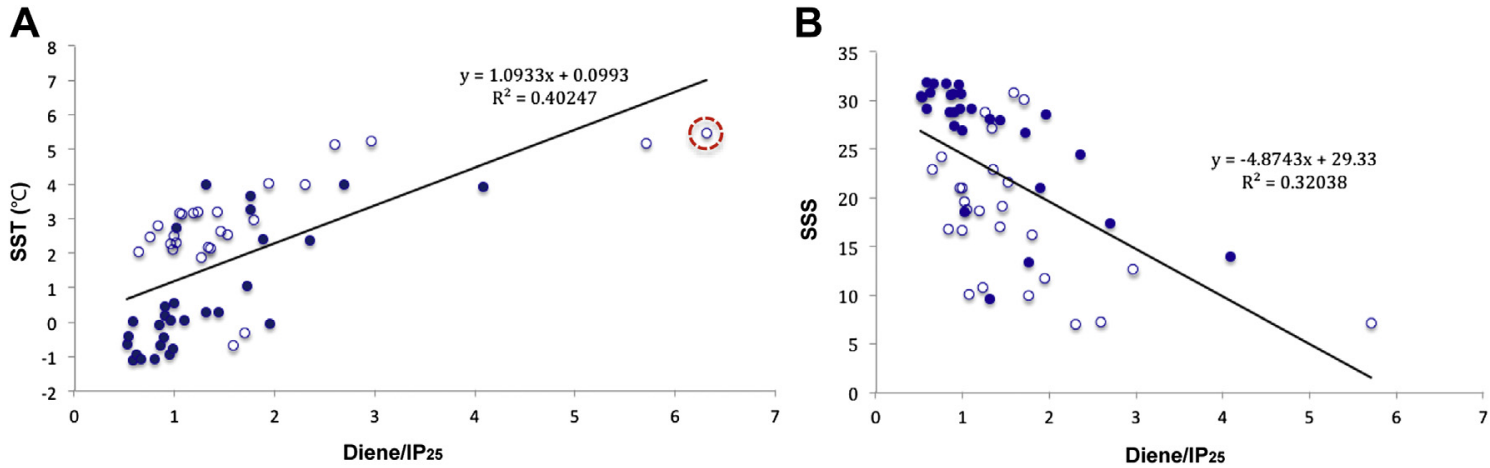

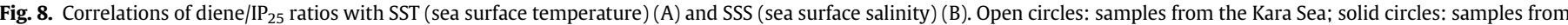

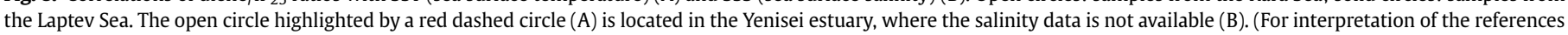
to colour in this figure legend, the reader is referred to the web version of this article.) 


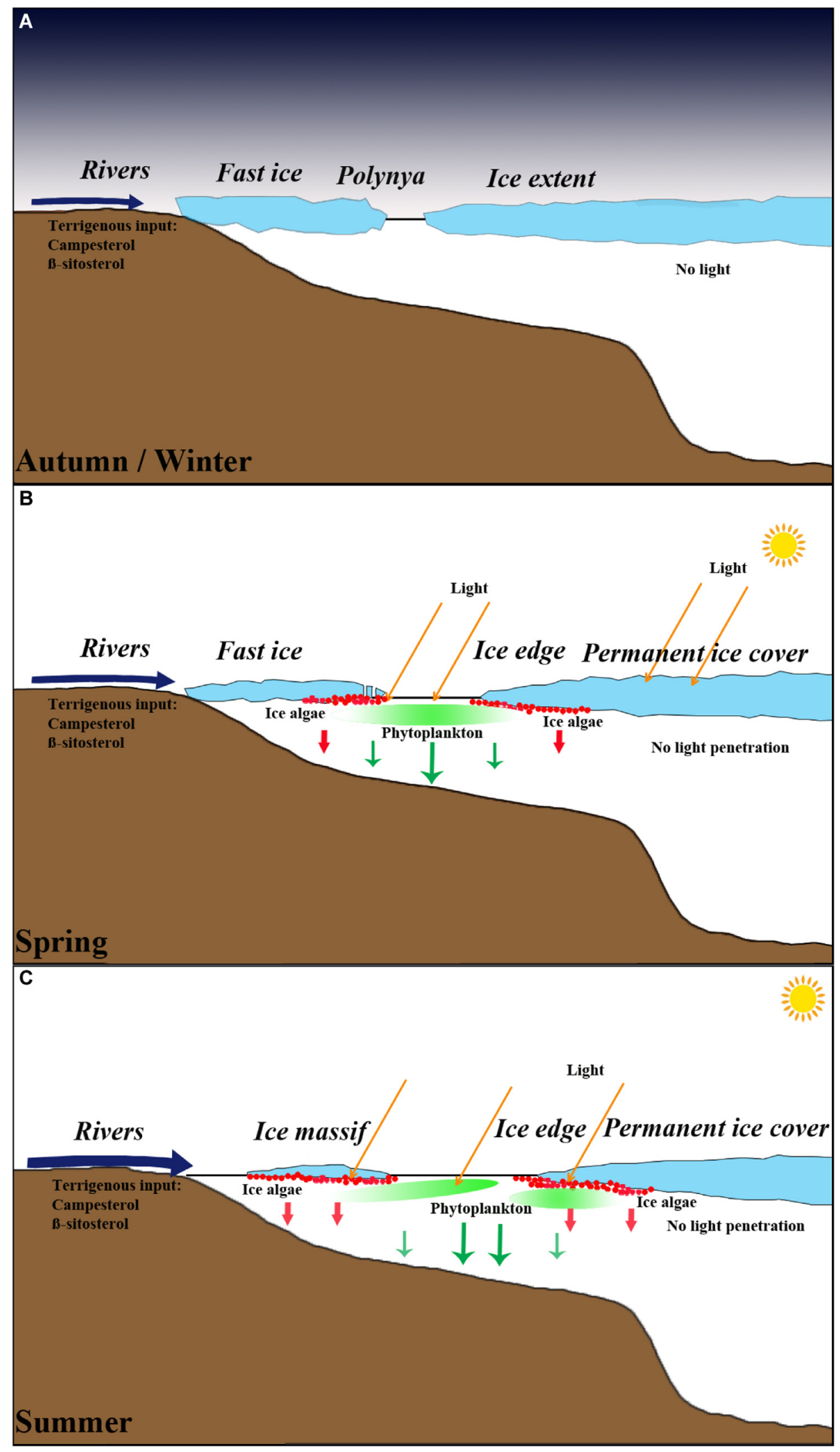

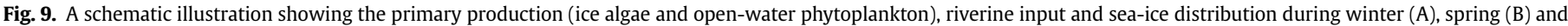
summer (C). 
sea-ice occurrence. In these areas, the seasonal sea-ice cover starts melting in spring and summer. The $\mathrm{P}_{\mathrm{B}} \mathrm{IP}_{25}$ index also diminishes towards the rivers and reaches low values $\left(\mathrm{P}_{\mathrm{B}} \mathrm{IP}_{25}, 0.22-0.33\right)$ in the vicinity of the estuaries (Fig. $5 \mathrm{~B}$ ), which points to ice-free conditions during summer. Increasing brassicasterol (Fig. 4A) concentrations indicate the growth of open-water phytoplankton, coinciding with the retreat of sea ice in summer. Furthermore, the absence of $\mathrm{IP}_{25}$ in the rivers confirms that this proxy exclusively is produced by marine sea-ice algae, for example, Haslea spp. including Haslea vitrea and Haslea crucigeroides (Round et al., 1990; Witkowski et al., 2000; Belt et al., 2007). $\mathrm{P}_{\mathrm{B}} \mathrm{IP}_{25}$ values of 0 are found directly in the $\mathrm{Ob}$ and Yenisei rivers caused by the absence of $\mathrm{IP}_{25}$, with the occurrence of low concentrations of phytoplankton biomarkers, reflecting the riverine environment. These data show that the absence of $\mathrm{IP}_{25}$ coinciding with zero (very low) phytoplankton biomarker concentrations may not only be caused by a permanent sea-ice cover (cf., Müller et al., 2009, 2011).

In contrast to the good correlation between $\mathrm{IP}_{25}$ and $\mathrm{PIP}_{25}$ with sea-ice concentration derived from satellite data described for the Fram Strait area (Müller et al., 2011), our data set does not show this correlation (Fig. S2, supplementary material). This may be explained by the more complex environmental situation in our study area, influenced by sea ice and fast-ice formation, occurrence of ice massifs and river discharge (see schematic illustration Fig. 9). The abundance of $\mathrm{IP}_{25}$ preserved in sediments controlled by variable factors, for example, transportation of ice algae in the water column, sediment deposition rates and sediment grain size. In our study area, the strong riverine discharge transports plenty of suspended matter to the inner estuaries and outer estuaries (Fahl et al., 2003; Stein et al., 2004; Rivera et al., 2006), which influences the transportation process, sedimentation rates and the formation and melting of sea ice. Furthermore, the occasional occurrence of ice massifs may provide favourable living conditions for sea-ice diatoms during summer, but is not shown in average sea-ice satellite distribution map.

\section{3. $C_{25}-\mathrm{HBI}$ monoene, diene and triene concentrations}

$\mathrm{C}_{25}$ highly branched isoprenoid (HBI) alkenes with different degrees of unsaturation, produced by diatom genera (e.g. Haslea ostrearia, Rhizosolenia setigera, Pleurosigma intermedium and Navicula sclesvicensis), have been determined in freshwater, seawater, marine sediments, and freshwater and marine species (Volkman et al., 1994; Belt et al., 2000, 2001a; Grossi et al., 2004; Massé et al., 2004). The extent of unsaturation in HBIs depends on the growth conditions and culture temperatures (Belt et al., 2000; Rowland et al., 2000). As mentioned above, the $\mathrm{C}_{25}$-HBI monoene $\left(\mathrm{IP}_{25}\right)$ has been used as novel promising ice proxy. In contrast, the $\mathrm{C}_{25}$-HBI diene and triene are found in marine sediments and diatoms from both polar areas and temperate regions (Gearing et al., 1976; Barrick et al., 1980; Volkman et al., 1983; Nichols et al., 1988; Wraige et al., 1997; Johns et al., 1999; Belt et al., 2007; Barbara et al., 2010; Denis et al., 2010; Massé et al., 2011). However, the $C_{25}$-HBI diene occurred in Antarctic sea ice, while the $\mathrm{C}_{25}-\mathrm{HBI}$ triene are found in Antarctic phytoplankton samples (Johns et al., 1999; Massé et al., 2011). Previous studies have commonly reported that the $\mathrm{C}_{25^{-}}$ $\mathrm{HBI}$ triene may become the predominant hydrocarbon fraction in coastal sediments and particulate matter from nutrient-rich environment, e.g. the Gulf of Mexico shelf, Florida, USA (Gearing et al., 1976), Puget Sound (Barrick et al., 1980) and upwelling zones off Peru (Volkman et al., 1983). In order to investigate the different sources of these compounds and their relation to environmental conditions, we herein compared the three HBIs alkenes with different extents of unsaturation by means of diene/IP 25 (Fig. 6C) and triene/IP 25 ratios (see supplementary material).
In our study area a good correlation between diene and $\mathrm{IP}_{25}$ concentrations is obvious (Fig. 7A), except for the samples in $\mathrm{Ob}$ and Yenisei rivers. Based on the similarity in the distributions of $\mathrm{IP}_{25}$ and diene (excluding samples in $\mathrm{Ob}$ and Yenisei rivers) (Figs. 5A and $6 \mathrm{~A})$, these two HBI alkenes probably originate from a common source, e.g. H. ostrearia, which has been identified as a major source of $\mathrm{C}_{25}$ HBIs in recent studies (Volkman et al., 1994; Wraige et al., 1997; Belt et al., 2000; Rowland et al., 2000; Massé et al., 2004). The distribution of the diene/ $/ \mathrm{IP}_{25}$ ratio increasing from north to south, especially in the Laptev Sea, reveals that the enrichment of $\mathrm{IP}_{25}$ is stronger than that of the diene in the north and decreases gradually towards the south (Fig. 6C; see also Vare et al., 2009). The increase in the diene/ $/ \mathrm{IP}_{25}$ ratio from north to south (Fig. $6 \mathrm{~A}$ ) seems to be in line with an increase of measured sea-surface temperature (Fig. 2D), as also reflected in the correlation plot of Fig. 7A. This observation supports the study by Rowland et al. (2000) who described an increase in unsaturation of HBIs with increasing seasurface temperature. Furthermore, Fahl and Stein (2012) found distinctly increased diene $/ \mathrm{IP}_{25}$ ratios during Bølling-Allerød warm intervals, followed by a decrease in diene/ $/ \mathrm{IP}_{25}$ ratios coinciding with the Holocene cooling trend, in a biomarker study of core PS2458 (see Fig. 1 for location). Based on these preliminary data, they propose that the diene/IP 25 ratio might be used as proxy for reconstruction of sea-surface temperature in Arctic lowtemperature environments, a hypothesis, however, that has to be approved by further data. Furthermore, the diene/ $\mathrm{IP}_{25}$ ratios show a negative correlation with the salinity distribution in our study area (Fig. 8B), suggesting that the increasing salinity may result in decreasing unsaturation to a certain extent. Wraige et al. (1998) reported the influence of salinity on the distribution of $\mathrm{C}_{25} \mathrm{HBI}$ alkenes in $H$. ostrearia. They concluded that the HBI concentrations (the only HBI observed was triene, which is consistent with the study of the effects of temperature on unsaturation in $\mathrm{C}_{25} \mathrm{HBI}$ alkenes of $H$. ostrearia) were slightly higher at salinities of 25-35 than those at salinities of 15 and 40 at $14-15{ }^{\circ} \mathrm{C}$, however, the salinity is not as important as other factors in controlling the productions of $\mathrm{C}_{25}$ HBI alkenes. Rowland et al. (2001) found that increased salinity from 15 to 35 at $18{ }^{\circ} \mathrm{C}$ decreased haslene production, and unsaturation in haslenes was not changed by increased salinity. The study of influence of salinity on the $C_{25} \mathrm{HBI}$ alkenes at low temperature is still limited.

The triene concentrations correlate less clearly with $\mathrm{IP}_{25}$ concentrations (Fig. S3C, supplementary material), but show a better correlation with diene concentrations (Fig. 7B), suggesting that the triene probably originates from a different (non-sea ice) source as the $\mathrm{IP}_{25}$ but has a common source with the diene. Considering the good correlation between diene and $\mathrm{IP}_{25}$, we suggest that the diene might be produced by a mixed diatom community, as also observed in Antarctic sea ice (Johns et al., 1999). Johns et al. (1999) and Massé et al. (2011) have found $\mathrm{C}_{25}$-HBIs triene in Antarctic phytoplankton, while in our study, the triene concentrations show poor correlations with phytoplankton biomarkers concentrations (both brassicasterol and dinosterol) (see supplementary material), suggesting that the triene is probably not derived from open-water phytoplankton in this area. Due to the generally low contents of trienes (Fig. 4C), the triene $/ \mathrm{IP}_{25}$ ratios are relatively low (see supplementary material). High triene/ $/ \mathrm{IP}_{25}$ ratios, however, occur in the estuaries of $\mathrm{Ob}$ and Yenisei rivers and along the east coast of Taymyr Peninsula, where relatively high concentrations of trienes were found, supporting that the formation of triene is enhanced along coastal area. Furthermore, the triene/ $/ \mathrm{IP}_{25}$ is not consistent with the SST distribution (see supplementary material) due to the unsuitable living conditions for the triene production (Rowland et al., 2000). We propose that the triene probably may also originate from the diatom species, Pleurosigma intermedium and 
Navicula slesvicensis, which have been observed in costal sediments and Arctic regions (Belt et al., 2000, 2001b; von Quillfeldt, 2000; Grossi et al., 2004).

\section{Conclusions}

Based on the concentration of $\mathrm{IP}_{25}$ and open-water phytoplankton biomarkers, we can conclude that a quite stable marginal ice zone exists along the continental shelf/slope of the Kara and Laptev seas during summer/early fall. Further to the north, lower $\mathrm{IP}_{25}$ and phytoplankton biomarker concentrations point to a more closed sea-ice cover situation. There are no $\mathrm{IP}_{25}$ and very low brassicasterol and dinosterol concentrations in the river mouths but high terrigenous biomarker (campesterol and $\beta$-sitosterol) concentrations due to the freshwater inflow transporting terrigenous matter to estuaries. In our study, $\mathrm{IP}_{25}$ and $\mathrm{PIP}_{25}$ do not show any clear and simple correlations with satellite sea-ice data due to the complex environmental situation characterized by sea ice, fast ice, polynyas and the occasional occurrence of ice massifs, and the influence of river discharge on transportation of sea-ice diatom and formation of sea ice.

The distribution patterns of $\mathrm{C}_{25}$ - $\mathrm{HBI}$ diene and $\mathrm{IP}_{25}$ are very similar suggesting a common (sea-ice) origin of both compounds. The diene/IP 25 ratio increases southwards correlating with an increase in sea-surface temperature and showing a negative correlation with salinity. The $\mathrm{C}_{25}-\mathrm{HBI}$ triene, on the other hand, has a less clear correlation with $\mathrm{IP}_{25}$ but correlates well with diene concentrations, suggesting that the diene probably originates from mixed diatom sources including a non-sea ice source, by which triene is produced.

\section{Acknowledgement}

We thank the Alfred Wegener Institute (Bremerhaven) and China Scholarship Council for the financial support. We are grateful to Xuezhu Wang (AWI, Bremerhaven) for offering the sea-ice satellite data. We thank two anonymous reviewers for numerous constructive suggestions for improving the manuscript.

\section{Appendix A. Supplementary material}

Supplementary material associated with this article can be found, in the online version, at http://dx.doi.org/10.1016/j. quascirev.2012.11.028.

\section{References}

Aagaard, K., Carmack, E.C., 1989. The role of sea ice and other fresh water in the Arctic circulation. Journal of Geophysical Research 94, 14485-14498.

Armand, L.K., Leventer, A., 2010. Palaeo sea ice distribution and reconstruction derived from the geological record. In: Thomas, D.N., Dieckmann, G.S. (Eds.), Sea Ice. Blackwell Publishing, Oxford, pp. 469-529.

Barbara, L., Crosta, X., Massé, G., Ther, O., 2010. Deglacial environments in eastern Prydz Bay, East Antarctica. Quaternary Science Reviews 29, 2731-2740.

Bareiss, J., Görgen, K., 2005. Spatial and temporal variability of sea ice in the Laptev Sea: analyses and review of satellite passive-microwave data and model results, 1979 to 2002. Global and Planetary Change 48, 28-54.

Barrick, R.C., Hedges, J.I., Peterson, M.L., 1980. Hydrocarbon geochemistry of the Puget Sound region-I. Sedimentary acyclic hydrocarbons. Geochimica et Cosmochimica Acta 44, 1349-1362.

Bauch, H.A., Erlenkeuser, H., Bauch, D., Mueller-Lupp, T., Taldenkova, E., 2004. Stable oxygen and carbon isotopes in modern benthic foraminifera from the Laptev Sea shelf: implications for reconstructing proglacial and profluvial environments in the Arctic. Marine Micropaleontology 51, 285-300.

Belchansky, G.I., Douglas, D.C., 2002. Seasonal comparisons of sea ice concentration estimates derived from SSM/I, OKEAN, and RADARSAT data. Remote Sensing of Environment 81, 67-81.

Belt, S.T., Allard, W.G., Massé, G., Robert, J.-M., Rowland, S.J., 2000. Highly branched isoprenoids (HBIs): identification of the most common and abundant sedimentary isomers. Geochimica et Cosmochimica Acta 64, 3839-3851.
Belt, S.T., Massé, G., Allard, W.G., Robert, J.-M., Rowland, S.J., 2001a. Identification of a $\mathrm{C}_{25}$ highly branched isoprenoid triene in the freshwater diatom Navicula sclesvicensis. Organic Geochemistry 32, 1169-1172.

Belt, S.T., Massé, G., Allard, W.G., Robert, J.-M., Rowland, S.J., 2001b. C25 highly branched isoprenoid alkenes in planktonic diatoms of the Pleurosigma genus. Organic Geochemistry 32, 1271-1275.

Belt, S.T., Massé, G., Rowland, S.J., Poulin, M., Michel, C., LeBlanc, B., 2007. A nove chemical fossil of palaeo sea ice: IP25. Organic Geochemistry 38, 16-27.

Belt, S.T., Vare, L.L., Massé, G., Manners, H.R., Price, J.C., MacLachlan, S.E., Andrews, J.T., Schmidt, S., 2010. Striking similarities in temporal changes to spring sea ice occurrence across the central Canadian Arctic Archipelago over the last 7000 years. Quaternary Science Reviews 29, 3489-3504.

Boon, J.J., Rijpstra, W.I.C., Lange, F.De., Leeuw, J.W.De., Yoshioka, M., Shimizu, Y. 1979. Black Sea sterol - a molecular fossil for dinoflagellate blooms. Nature 277 (1979), 125-127.

Comiso, J.C., Parkinson, C.L., 2004. Satellite-observed changes in the Arctic. Physics Today $57,38-44$

Cremer, H., 1999. Distribution patterns of diatom surface sediment assemblages in the Laptev Sea (Arctic Ocean). Marine Micropaleontology 38, 39-67.

Denis, D., Crosta, X., Barbara, L., Massé, G., Renssen, H., Ther, O., Giraudeau, J. 2010. Sea ice and wind variability during the Holocene in East Antarctica: insight on middle-high latitude coupling. Quaternary Science Reviews 29, 3709-3719.

Dethleff, D., Loewe, P., Kleine, E., 1998. The Laptev Sea flaw lead-detailed investigation on ice formation and export during 1991/1992 winter season. Cold Regions Science and Technology 27, 225-243.

Dieckmann, G.S., Hellmer, H.H., 2010. The importance of sea ice: an overview. In: Thomas, D.N., Dieckmann, G.S. (Eds.), Sea Ice. Blackwell Publishing, Oxford, pp.1-22.

Divine, D.V., Korsnes, R., Makshtas, A.P., 2004. Temporal and spatial variation of shore-fast ice in the Kara Sea. Continental Shelf Research 24, 1717-1736.

Eicken, H., Reimnitz, E., Alexandrov, V., Martin, T., Kassens, H., Viehoff, T., 1997. Seaice processes in the Laptev Sea and their importance for sediment export. Continental Shelf Research 17, 205-233.

Fahl, K., Stein, R., 1997. Modern organic-carbon-deposition in the Laptev Sea and the adjacent continental slope: surface-water productivity vs. terrigenous supply. Organic Geochemistry 26 (5/6), 379-390.

Fahl, K., Stein, R., 1999. Biomarkers as organic-carbon-source and environmental indicators in the Late Quaternary Arctic Ocean: problems and perspectives. Marine Chemistry 63, 293-309.

Fahl, K., Stein, R., 2007. Biomarker records, organic carbon accumulation, and river discharge in the Holocene southern Kara Sea (Arctic Ocean). Geo-Marine Letters $27,13-25$.

Fahl, K., Stein, R., 2012. Modern seasonal variability and deglacial/Holocene change of central Arctic Ocean sea-ice cover: New insights from biomarker proxy records. Earth and Planetary Science Letters 351-352, 123-133.

Fahl, K., Cremer, H., Erlenkeuser, H., Hansserr, H., Hölemann, J., Kassens, H. Knickmeier, K., Kosobokova, K., Pirrung, M.K., Lindemann, F., Markhaseva, E. Lischka, S., Petryashov, V., Piepenburg, D., Schmid, M., Spindler, M., Stein, R., Tuschling, K., 2001. Sources and pathways of organic carbon in the modern Laptev Sea (Arctic Ocean): implications from biological, geochemical and geological data. Polarforschung 69 (1999), 193-205.

Fahl, K., Stein, R., Gaye-Haake, B., Gebhardt, C., Kodina, L.A., Unger, D., Ittekkot, V. 2003. Biomarkers in surface sediments from $\mathrm{Ob}$ and Yenisei estuaries and southern Kara Sea: evidence for particulate organic carbon sources, pathways, and degradation. In: Stein, R., Fahl, K., Fütterer, D.K., Galimov, E.M., Stepanets, O.V. (Eds.), Siberian River Run-off in the Kara Sea: Characterisation, Quantification, Variability, and Environmental Significance. Proceeding of Marine Science, vol. 6. Elsevier, Amsterdam, pp. 329-348.

Fernandes, M.B., Sicre, M.A., 2000. The importance of terrestrial organic carbon inputs on Kara Sea shelves as revealed by n-alkanes, OC and $\delta^{13} \mathrm{C}$ values. Organic Geochemistry 31, 363-374.

Francis, J.A., Hunter, E., Key, J.R., Wang, X.J., 2005. Clues to variability in Arctic minimum sea ice extent. Geophysical Research Letters, L21501.

Fütterer, D., 1994. Die Expedition ARCTIC'93, der Fahrtabschnitt ARK-IX/4 mit FS "POLARSTERN" 1993. Reports on Polar Research. Alfred Wegener Institute for Polar and Marine Research, Bremerhaven. 149pp.

Gaye, B., Fahl, K., Kodina, L.A., Lahajnar, N., Nagel, B., Unger, D., Gebhardt, A.C., 2007. Particulate matter fluxes in the southern and central Kara Sea compared to sediments: bulk fluxes, amino acids, stable carbon and nitrogen isotopes, sterols and fatty acids. Continental Shelf Research 27, 2570-2594.

Gearing, P., Gearing, J.N., Lytle, T.F., Lytle, J.S., 1976. Hydrocarbons in 60 northeas Gulf of Mexico shelf sediments: a preliminary survey. Geochimica et Cosmochimica Acta 40, 1005-1017.

Grossi, V., Beker, B., Geenevasen, J.A.J., Schouten, S., Raphel, D., Fontaine, M.-F, Damsté, J.S.S., 2004. C25 highly branched isoprenoid alkenes from the marine benthic diatom Pleurosigma strigosum. Phytochemistry 65 (22), 3049-3055.

Huang, W.Y., Meinschein, W.G., 1976. Sterols as source indicators of organic material in sediments. Geochimica et Cosmochimica Acta 40, 323-330.

Johannessen, O.M., Miles, M., Bjorgo, E., 1995. The Arctic's shrinking sea ice. Nature $376,126-127$.

Johannessen, O.M., Shalina, E.V., Miles, M.W., 1999. Satellite evidence for an Arctic sea ice cover in transformation. Science 286, 1937-1939.

Johns, L., Wraige, E.J., Belt, S.T., Lewis, C.A., Masse, G., Robert, J.M., Rowland, S.J., 1999. Identification of a C-25 highly branched isoprenoid (HBI) diene in Antarctic sediments, Antarctic sea-ice diatoms and cultured diatoms. Organic Geochemistry 30 (11), 1471-1475. 
Jones, E.P., 2001. Circulation in the Arctic Ocean. Polar Research 20, 139-146.

Karklin, V.P., Kalerin, I.D., Gorbunov, Y.A., Losev, S.M., 2007. Eastern part of the Northern Sea route. In: Johannessen, O.M., Alexandrov, V.Yu., Frolov, I.Ye. Sandven, S., Pettersson, L.H., Bobylev, L.P., Kloster, K., Smirnov, V.G. Mironov, Ye.U., Babich, N.G. (Eds.), Remote Sensing of Sea Ice in the Northern Sea Route: Studies and Applications. Springer and Praxis Publishing, Berlin and Chichester.

Kassens, H., Karpiy, V.Y., 1994. Russian-German cooperation: the transdrift I expedition to the Laptev sea. Reports on Polar Research, 151-168.

Kern, S., 2008. Polynya area in the Kara Sea, Arctic, obtained with microwave radiometry for 1979-2003. Geoscience and Remote Sensing Letters, IEEE 5, $171-175$.

Knies, J., Kleiber, H.-P., Matthiessen, J., Müller, C., Nowaczyk, N., 2001. Marine icerafted debris records constrain maximum extent of Saalian and Weichselian ice-sheets along the northern Eurasian margin. Global and Planetary Change 31 45-64.

Krishnamurthy, R.V., Machavaram, M., Baskaran, M., Brooks, J.M., Champs, M.A., 2001. Organic carbon flow in the Ob, Yenisei rivers and Kara Sea of the Arctic region. Marine Pollution Bulletin 42, 726-732.

Lisitsyn, A.P., Vinogradov, M.E., 1995. International high-latitude expedition in the Kara Sea (the 49th cruise of the R/V Dmitriy Mendeleev). Oceanology of the Russian Academy of Sciences 34, 583-590.

Lisitzin, A.P., 1995. The marginal filter of the ocean. Oceanology 34 (5), 671-682.

Martin, S., Cavalieri, D.J., 1989. Contributions of the Siberian shelf polynyas to the Arctic Ocean Intermediate and deep water. Journal of Geophysical Research 94 $12725-12738$.

Massé, G., Belt, S.T., Rowland, S.J., Rohmer, M., 2004. Isoprenoid biosynthesis in the diatoms Rhizosolenia setigera (Brightwell) and Haslea ostrearia (Simonsen). Proceedings of the National Academy of Sciences of the United States of America 101, 4413-4418.

Massé, G., Rowland, S.J., Sicre, M.A., Jacob, J., Jansen, E., Belt, S.T., 2008. Abrupt climate changes for Iceland during the last millennium: evidence from high resolution sea ice reconstructions. Earth and Planetary Science Letters 269, 565-569.

Massé, G., Belt, S.T., Crosta, X., Schmidt, S., Snape, I., Thomas, D.N., Rowland, S.J 2011. Highly branched isoprenoids as proxies for variable sea ice conditions in the Southern Ocean. Antarctic Science 23 (5), 487-498.

Meese, D.A., Reimnitz, E., Tucker III, W.B., Gow, A.J., Bischof, J., Darby, D., 1997. Evidence for radionuclide transport by sea ice. Science of the Total Environment 202, 267-278.

Mironov, Ye.U., Gudkovich, Z.M., Karklin, V.P., 2007a. The Arctic Eurasian shelf seas. In: Johannessen, O.M., Alexandrov, V.Yu., Frolov, I.Ye., Sandven, S. Pettersson, L.H., Bobylev, L.P., Kloster, K., Smirnov, V.G., Mironov, Ye.U. Babich, N.G. (Eds.), Remote Sensing of Sea Ice in the Northern Sea Route: Studies and Applications. Springer and Praxis Publishing, Berlin and Chichester.

Mironov, Ye.U., Frolov, I.Ye., Spichkin, V.A., Karklin, V.P., Kalerin, I.D., Gorbunov, Y.A Losev, S.M., 2007b. Western part of the Northern Sea route. In: Johannessen, O.M., Alexandrov, V.Yu., Frolov, I.Ye., Sandven, S., Pettersson, L.H. Bobylev, L.P., Kloster, K., Smirnov, V.G., Mironov, Ye.U., Babich, N.G. (Eds.), Remote Sensing of Sea Ice in the Northern Sea Route: Studies and Applications. Springer and Praxis Publishing, Berlin and Chichester.

Müller, J., Massé, G., Stein, R., Belt, S.T., 2009. Variability of sea-ice conditions in the Fram Strait over the past 30,000 years. Nature Geoscience 2, 772-776.

Müller, J., Wagner, A., Fahl, K., Stein, R., Prange, M., Lohmann, G., 2011. Towards quantitative sea ice reconstructions in the northern North Atlantic: a combined biomarker and numerical modelling approach. Earth and Planetary Science Letters 306, 137-148.

Nichols, P.D., Volkman, J.K., Palmisano, A.C., Smith, G.A., White, D.C., 1988. Occurrence of an isoprenoid $\mathrm{C}_{25}$ diunsaturated alkene and high neutral lipid content in Antarctic sea-ice diatom communities. Journal of Phycology 24, 90-96.

Nürnberg, D., Wollenburg, I., Dethleff, D., Eicken, H., Kassens, H., Letzig, T., Reimnitz, E., Thiede, J., 1994. Sediments in Arctic sea ice: implications for entrainment, transport and release. Marine Geology 119, 185-214.

Parkinson, C.L., Cavalieri, D.J., Gloersen, P., Zwally, H.J., Comiso, J.C., 1999. Arctic sea ice extents, areas, and trends, 1978-1996. Journal of Geophysical Research 104, 20837-20856.

Peterson, B.J., Holmes, R.M., McClelland, J.W., Vörösmarty, C.J., Lammers, R.B., Shiklomanov, A.I., Shiklomanov, I.A., Rahmstorf, S., 2002. Increasing river discharge to the Arctic Ocean. Science 298, 2171-2173.

Pfirman, S.L. Kogeler, J., Anselme, B., 1995. Coastal environments of the western Kara and eastern Barents Seas. Deep Sea Research Part II: Topical Studies in Oceanography $42,1391-1412$.

Pfirman, S.L., Kögeler, J.W., Rigor, I., 1997. Potential for rapid transport of contaminants from the Kara Sea. Science of the Total Environment 202, 111-122.

Polyakova, Ye.I., 2003. Diatom assemblages in surface sediments of the Kara Sea (Siberian Arctic) and their relationship to oceanological conditions. In: Stein, R. Fahl, K., Fütterer, D.K., Galimov, E.M., Stepanets, O.V. (Eds.), Siberian River Runoff in the Kara Sea: Characterisation, Quantification, Variability, and Environmental Significance. Proceeding of Marine Science, vol. 6. Elsevier, Amsterdam, pp. 401-432.

Polyakova, Ye.I., Stein, R., 2004. Holocene paleoenvironmental implications of diatom and organic carbon records from the southeastern Kara Sea (Siberian Margin). Quaternary Research 62, 256-266.

Polyakov, I.V., Alekseev, G.V., Bekryaev, R.V., Bhatt, U.S., Colony, R., Johnson, M.A. Karklin, V.P., Walsh, D., Yulin, A.V., 2003. Long-term ice variability in Arctic marginal seas. Journal of Climate 16, 2078-2085.
Rachold, V., Hubberten, H.-W., 1999. Carbon isotope composition of particulate organic material in East Siberian rivers. In: Kassens, H., Bauch, $\mathrm{H}$. Dmitrenko, I., Eicken, H., Hubberten, H.W., Melles, M., Thiede, J., Timokhov, L. (Eds.), Land-ocean Systems in the Siberian: Dynamics and History. Springer, Berlin, pp. 223-238.

Rayner, N.A., Parker, D.E., Horton, E.B., Folland, C.K., Alexander, L.V., Rowell, D.P., Kent, E.C., Kaplan, A., 2003. Global analyses of sea surface temperature, sea ice, and night marine air temperature since the late nineteenth century. Journal of Geophysical Research 108, 4407.

Rivera, J., Karabanov, E.B., Williams, D.F., Buchinskyi, V., Kuzmin, M., 2006. Lena River discharge events in sediments of Laptev Sea, Russian Arctic. Estuarine, Coastal and Shelf Science 66, 185-196.

Rothrock, D.A., Yu, Y., Maykut, G.A., 1999. Thinning of the Arctic sea-ice cover. Geophysical Research Letters 26 (23), 3469-3472.

Round, F.E., Crawford, R.M., Mann, D.G., 1990. The Diatoms: Biology and Morphology of the Genera. Cambridge University Press, Cambridge, pp. 576-577.

Rowland, S.J., Belt, S.T., Wraige, E.J., Massé, G., Roussakis, C., Robert, J.M., 2000. Effects of temperature on polyunsaturation in cytostatic lipids of Haslea ostrearia. Phytochemistry 56, 597-602.

Rowland, S.J., Allard, W.G., Belt, S.T., Massé, G., Robert, J.M., Blackburn, S. Frampton, D., Revill, A.T., Volkman, J.K., 2001. Factors influencing the distributions of polyunsaturated terpenoids in the diatom, Rhizosolenia setigera. Phytochemistry $58,717-728$.

Schauer, U., Muench, R.D., Rudels, B., Timokhov, L., 1997. Impact of Eastern Arctic shelf waters on the Nansen Basin intermediate layers. Journal of Geophysical Research 102, 3371-3382.

Schauer, U., 2012. The Expedition of the Research Vessel "Polarstern" to the Arctic in 2011 (ARK-XXVI/3 - TransArc). Reports on Polar and Marine Research 649, 205.

Schlitzer, R., 2012. Ocean Data View. http://odv.awi.de/.

Schoster, F., Levitan, M., 2003. Scientific cruise report of the joint Russian-German Kara Sea expedition in 2002 with RV "Akademik Boris Petrov". Berichte zur Polarforschung und Meeresforschung. ISSN: 1618-3193 450. ISSN: 16183193.

Siegel, V., Holm-Hansen, O., Hewitt, R., Fraser, W., Trivelpiece, W., Trivelpiece, S., 1997. Effects of sea-ice extent and krill or salp dominance on the Antarctic food web. Nature 387, 897-900.

Stein, R., 2008. Arctic Ocean sediments: processes, proxies, and paleoenvironment In: Developments in Marine Geology, vol. 2. Elsevier, Amsterdam, 592 pp.

Stein, R., Fahl, K., 2004a. The Kara Sea: distribution, sources, variability and burial of organic carbon. In: Stein, R., Macdonald, R.W. (Eds.), The Organic Carbon Cycle in the Arctic Ocean. Springer, Berlin, pp. 237-266.

Stein, R., Fahl, K., 2004b. The Laptev Sea: distribution, sources, variability and burial of organic carbon. In: Stein, R., Macdonald, R.W. (Eds.), The Organic Carbon Cycle in the Arctic Ocean. Springer, Berlin, pp. 213-237.

Stein, R., Fahl, K., 2013. Biomarker proxy shows potential for studying the entire Quaternary Arctic sea ice history. Organic Geochemistry 55, 98-102.

Stein, R., Stepanets, O., 2001. The German-Russian Project on Siberian River Run-off (SIRRO): scientific cruise report of the Kara-Sea expedition "SIRRO 2000" of RV "Akademik Boris Petrov" and first results. Berichte zur Polarforschung und Meeresforschung. ISSN: 0176-5027 393. ISSN: 0176-5027.

Stein, R., Stepanets, O., 2002. Scientific cruise report of the Kara sea expedition 2001 of RV "Akademik Boris Petrov": the German-Russian project on Siberian river run-off (SIRRO) 2nd the EU-Project "ESTABLISH". Berichte zur Polarforschung und Meeresforschung. ISSN: 1618-3193 419. ISSN: 1618-3193.

Stein, R., Fahl, K., Fütterer, D.K., Galimov, E.M., Stepanets, O.V., 2003. Siberian River run-off in the Kara Sea: characterisation, quantification, variability, and environmental significance. In: Proceeding of Marine Science, vol. 6. Elsevier, Amsterdam, $487 \mathrm{pp}$

Stein, R., Dittmers, K., Fahl, K., Kraus, M., Matthiessen, J., Niessen, F., Pirrung, M., Polyakova, Y., Schoster, F., Steinke, T., Fütterer, D.K., 2004. Arctic (palaeo) river discharge and environmental change: evidence from the Holocene Kara Sea sedimentary record. Quaternary Science Reviews 23, 1485-1511.

Stein, R., Fahl, K., Müller, J., 2012. Proxy reconstruction of Cenozoic Arctic Ocean seaice history - from IRD to IP25 -. Polarforschung 82 (1), 37-71.

Stroeve, J.C., Serreze, M.C., Fetterer, F., Arbetter, T., Meier, W., Maslanik, J., Knowles, K., 2005. Tracking the Arctic's shrinking ice cover: another extreme September minimum in 2004. Geophysical Research Letters 32, L04501.

Stroeve, J., Holland, M.M., Meier, W., Scambos, T., Serreze, M., 2007. Arctic sea ice decline: faster than forecast. Geophysical Research Letters 34, L09501.

Stroeve, J., Frei, A., McCreight, J., Ghatak, D., 2008. Arctic sea-ice variability revisited. Annals of Glaciology 48, 71-81.

Thomas, D.N., Dieckmann, G.S., 2010. Sea Ice. Blackwell Publishing, Oxford, 640 pp.

Vare, L.L., Mass, G., Gregory, T.R., Smart, C.W., Belt, S.T., 2009. Sea ice variations in the central Canadian Arctic Archipelago during the Holocene. Quaternary Science Reviews 28 (13-14), 1354-1366.

Volkman, J.K., 1986. A review of sterol markers for marine and terrigenous organic matter. Organic Geochemistry 9, 83-99.

Volkman, J.K., Farrington, J.W., Gagosian, R.B., Wakeham, S.G., 1983. Lipid composition of coastal marine sediments from the Peru upwelling region. In: Bjoroy, M. (Ed.), Advances in Organic Geochemistry 1981. Wiley, Chichester, UK, pp. 228-240.

Volkman, J.K., Barrett, S.M., Dunstan, G.A., 1994. C25 and C30 highly branched alkenes in laboratory cultures of two marine diatoms. Organic Geochemistry 21, 407-413. 
von Quillfeldt, C.H., 2000. Pleurosigma tenuiforme spec. nov.; a marine Pleurosigma species with long, slender apices, occurring in Arctic. Diatom Research 15, $221-$ 236

Walsh, J.E., Chapman, W.L., 2001. Twentieth-century sea ice variations from observational data. Annals of Glaciology 33, 444-448.

Witkowski, A., Lange-Bertalot, H., Metzeltin, D., 2000. Diatom flora of marine coasts I. In: Lange-Bertalot, H. (Ed.), Iconographia Diatomologica, 7, pp. 223-225.

Wollenburg, J., Kuhnt, W., Mackensen, A., 2001. Changes in Arctic Ocean paleoproductivity and hydrography during the last 145kyr: the benthic foraminiferal record. Paleoceanography 16 (1), 65-77.
Wollenburg, J., Knies, J., Mackensen, A., 2004. High-resolution palaeoproductivity fluctuations during the past $24 \mathrm{kyr}$ as indicated by benthic foraminifera in the margina Arctic Ocean. Palaeogeography, Palaeoclimatology, Palaeoecology 204, 209-238.

Wraige, E.J., Belt, S.T., Lewis, C.A., Cooke, D.A., Robert, J.-M., Massé, G., Rowland, S.J., 1997. Variations in structures and distributions of C25 highly branched isoprenoid (HBI) alkenes in cultures of the diatom, Haslea ostrearia (Simonsen). Organic Geochemistry 27, 497-505.

Wraige, E.J., Belt, S.T., Massé, G., Robert, J.M., Rowland, S.J., 1998. Variations in distributions of C25 highly branched isoprenoid (HBI) alkenes in the diatom, Haslea ostrearia: influence of salinity. Organic Geochemistry 28, 855-859. 